\title{
Growth with perfect capital movements in CES: US debt dynamics and model estimation
}

Citation for published version (APA):

Ziesemer, T. H. W. (2005). Growth with perfect capital movements in CES: US debt dynamics and model estimation. UNU-MERIT, Maastricht Economic and Social Research and Training Centre on Innovation and Technology. MERIT-Infonomics Research Memorandum Series No. 014 https://doi.org/10.26481/umamer.2005014

Document status and date:

Published: 01/01/2005

DOI:

10.26481/umamer.2005014

Document Version:

Publisher's PDF, also known as Version of record

\section{Please check the document version of this publication:}

- A submitted manuscript is the version of the article upon submission and before peer-review. There can be important differences between the submitted version and the official published version of record.

People interested in the research are advised to contact the author for the final version of the publication, or visit the DOI to the publisher's website.

- The final author version and the galley proof are versions of the publication after peer review.

- The final published version features the final layout of the paper including the volume, issue and page numbers.

Link to publication

\footnotetext{
General rights rights.

- You may freely distribute the URL identifying the publication in the public portal. please follow below link for the End User Agreement:

www.umlib.nl/taverne-license

Take down policy

If you believe that this document breaches copyright please contact us at:

repository@maastrichtuniversity.nl

providing details and we will investigate your claim.
}

Copyright and moral rights for the publications made accessible in the public portal are retained by the authors and/or other copyright owners and it is a condition of accessing publications that users recognise and abide by the legal requirements associated with these

- Users may download and print one copy of any publication from the public portal for the purpose of private study or research.

- You may not further distribute the material or use it for any profit-making activity or commercial gain

If the publication is distributed under the terms of Article $25 \mathrm{fa}$ of the Dutch Copyright Act, indicated by the "Taverne" license above, 


\section{MERIT-Infonomics Research Memorandum series}

Growth with perfect capital movements in CES:

US Debt Dynamics and model estimation

\section{Thomas Ziesemer}

\section{5-014}

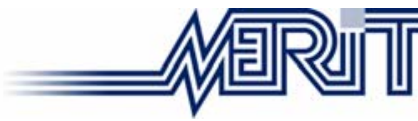

MERIT - Maastricht Economic Research Institute on Innovation and Technology

PO Box 616

6200 MD Maastricht

The Netherlands

T: +31433883875

F: +31433884905

http://www.merit.unimaas.nl e-mail:secr-merit@merit.unimaas.nl

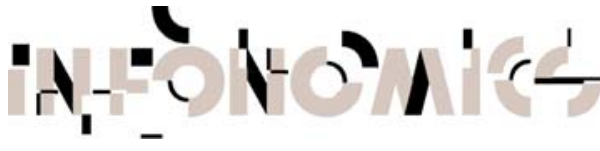

International Institute of Infonomics

c/o Maastricht University PO Box 616

6200 MD Maastricht The Netherlands

T: +31 433883875

$\mathrm{F}:+31453884905$

http://www.infonomics.nl e-mail: secr@infonomics.nl 


\title{
Growth with perfect capital movements in CES: US debt dynamics and model estimation
}

\author{
Thomas Ziesemer, Department of Economics and MERIT, University of Maastricht. ${ }^{1}$
}

Abstract. We derive the central differential equation of the neoclassical growth model for the case of a CES (constant elasticity of substitution) production function with perfect capital movement in terms of the debt/GDP ratio and estimate it in several ways for the United States and in a later step the whole model. Debt data are derived from the accumulation of differences between investment and we show that then valuation effects play a minor role. The result is that the US debt/GDP ratio follows the pattern of a stable differential equation, which will lead to a long-run debtor position. The debt/GDP ratio will approach a value between $50 \%$ and $60 \%$ (depending on the specification used) unless a structural break increases the world interest rates or, similarly, US spreads reduce the US demand for foreign debt. A value of 50\% will be achieved around 2040 . We also find short-run deviations from this long-run path, which are characterized by nonsustainable explosive debt growth. These phases are characterized by high interest rates and followed by devaluations of the dollar. Our simple method allows detecting such phases early on. The estimation of the whole model yields an elasticity of substitution for capital and labour of .155 with autocorrelation correction (and 1/3 without), a growth rate of labour-augmenting technical change of $1.65 \%$ (1.5\%) and a corresponding initial level of labour productivity as of 1959 of about 350 (320).

JEL code: F21, F43, O 40.

Keywords: Growth, long run capital movements, productivity, time-varying coefficients, nonlinear GMM growth model estimation.

\footnotetext{
${ }^{1}$ P.O.Box 616, NL 6200 MD Maastricht. T.Ziesemer@algec.unimaas.nl ${ }^{1}$. Phone: ++31-433883872. I am grateful to Clemens Kool for some input in the beginning phase of working on this paper.
} 


\section{Growth with perfect capital movements in CES: US Debt Dynamics and model estimation}

Abstract. We derive the central differential equation of the neoclassical growth model for the case of a CES (constant elasticity of substitution) production function with perfect capital movement in terms of the debt/GDP ratio and estimate it in several ways for the United States and in a later step the whole model. Debt data are derived from the accumulation of differences between investment and we show that then valuation effects play a minor role. The result is that the US debt/GDP ratio follows the pattern of a stable differential equation, which will lead to a long-run debtor position. The debt/GDP ratio will approach a value between $50 \%$ and $60 \%$ (depending on the specification used) unless a structural break increases the world interest rates or, similarly, US spreads reduce the US demand for foreign debt. A value of 50\% will be achieved around 2040 . We also find short-run deviations from this long-run path, which are characterized by nonsustainable explosive debt growth. These phases are characterized by high interest rates and followed by devaluations of the dollar. Our simple method allows detecting such phases early on. The estimation of the whole model yields an elasticity of substitution for capital and labour of .155 with autocorrelation correction (and 1/3 without), a growth rate of labour-augmenting technical change of $1.65 \%$ (1.5\%) and a corresponding initial level of labour productivity as of 1959 of about 350 (320).

\section{Introduction}

Since some years the business press reports about more and more people worrying about the increasing foreign debt of the USA. In this paper we look at the dynamics of debt per unit of GDP for the United States from a theoretical and an empirical perspective, starting with some descriptive work and then estimating the debt dynamics as derived from the neoclassical growth model with perfect capital mobility. In Section 2 we look at some basic data in order to show that the problem is not yet serious in terms of current levels. In Section 3 we derive the dynamic equation for debt per unit of GDP from the neoclassical growth model using a CES function. In section 4 we estimate that central differential equation in three different ways in order to see whether or not the current trend is sustainable and which short-term deviations from the trend did cause short-term problems in the past. In section 5 we estimate the whole model using a CES production function. 


\section{Some characteristics of current US debt}

In Table 1 the third column (the difference of columns one and two) indicates net assets of the USA since 1980. In 1989 the U.S.A. became a net debtor. However, columns three and four indicate that the net income from this debtor position has been positive up until now. As the difference is between 0.7 and 1.3 percent this is mostly due to valuation effects. After 1997 net investment income has become negative according to the IMF IFSY (2001), but the data from IMF IFSY (2004) show still a positive net investment income. Revaluations (claims of the USA are often denominated in EUROs) clearly play an important role here (see Tille 2003; Cavallo 2004; Lane and Milesi-Ferretti 2001). As the net international investment position yields small differences in interest rates paid and received, the debt position of the United States is far from dangerously large.

\section{TABLE 1 ABOUT HERE}

As financial data suffer from (re-)valuation problems we prefer to construct the data from the difference between investment and savings, which is the driving force behind the debt increase and less bothered by valuation problems. This difference in nominal terms is presented in the first column of Appendix B Data. Since 1976 this value has always been positive. In our view this is the essence of debt accumulation. ${ }^{2}$ Running a regression of the natural log of investment minus savings, (I-S), on the time variable (see Table 2) reveals that the difference between nominal investment and savings has an average growth rate of almost $14 \%$, which is slightly decreasing though. On the other hand the nominal GDP has a growth rate of only $7.6 \%$ (see second regression in Table 2). These simple results from regressions with nominal flow variables might suggest that the U.S.A. is on a non-sustainable debt path. In order to analyze this more rigorously we derive the debt dynamics of debt per unit of GDP from the neoclassical growth model with perfect capital movements and estimate it.

\footnotetext{
${ }^{2}$ It may have been reinforced by shifts in US preferences towards foreign assets and goods (see Blanchard et al. 2005) to the extent that portfolios and the trade balance have an impact on the difference between investment and savings.
} 


\section{TABLE 2 OVER HERE}

\section{The Model}

We return to an older literature that focuses on simple debt dynamics. The model by Amano (1965) is the simplest variant of a model type, which generates conditions under which the traditional idea of a debt cycle can be shown to hold or not to hold respectively. We will use the model to show analytically that a dynamic debt process can be derived graphically with several possible outcomes summarized in Figure 1.

These outcomes can be dichotomized as follows. First, a debtor country can be on a stable path towards a steady state. In the final steady state, the country will remain a debtor if its saving ratio is low. However, it can also become a creditor in the steady state if its saving ratio is high enough. Second, the country can be on an unstable path without ending up in a steady state. In that case, the country can become a permanent creditor - again if it's saving ratio is high enough or the initial value of the debt/GDP ratio is low enough. Amano (1965) emphasizes the latter case, in which the country's GNP is dominated by foreign income and grows at a rate higher than the natural rate. Alternatively, the country can be situated on the other arm of the unstable path and experience an exploding debt, inevitably leading to a crisis. We derive each of these cases and the underlying assumptions below from a linear differential equation in debt per unit of GDP. Subsequently, we estimate these equations for the United States for the whole period 1960-2002, for shorter periods, and for time-varying coefficients. One of our purposes is to show that a country's debt dynamics can switch empirically between the stable and unstable paths over time in response to unexpected shocks although the long-run trend may be sustainable.

We start from a simple neoclassical growth model with a fixed rate of interest, $r$. Due to the assumption of perfect international capital mobility the domestic interest rate is exogenous and, in the first instance, fixed at the level of the world interest rate. In addition, we assume that output $(Y)$ is produced by the production factors capital $(K)$ and labor $(L)$ with labor-augmenting 
technology $(A)$. The production function is linearly homogeneous with positive first and negative second partial derivatives of an argument (or CES with $1 / 1-\rho$ as the elasticity of substitution):

$$
Y=F(K, A L), \quad Y=\left[\beta K^{\rho}+(1-\beta)(A L)^{\rho}\right]^{1 / \rho}
$$

The budget of the firm in terms of goods then is $Y-r K-w L-\delta K$, which will be zero under perfect competition in all markets, which can also be shown using marginal productivity results. Profit maximization of the representative firm yields the marginal productivity condition

$$
r+\delta=f^{\prime}(k)=\beta K^{\rho-1} Y^{(1-\rho)}=\beta(Y / K)^{1-\rho} \text { with } \quad k \equiv K / A L \quad \text { and } \quad \hat{K}=\hat{A}+\hat{L} \equiv g
$$

Since interest and depreciation, $\delta$, are given, the marginal productivity condition determines the capital/efficient-labor ratio and the capital-output ratio. The capital stock $K$ consists of domestic capital $W$ and foreign capital or debt $D$. Conditional on the level of the domestic stock of capital $W$, the country can choose its desired level of foreign indebtedness $D$ to make equation (2) hold at any moment. The labor force $L$ grows at an exogenous rate $n$. In the steady state the capital stock $K$ and output $Y$ grow at the same constant rate $g$, keeping $k$ constant. However, if interest and depreciation vary, $K / Y$ and $k$ could also vary. ${ }^{3}$

Households get net national income, which can be used for consumption C or savings S. This yields the budget $Y-r D-\delta K-C-S=0$. Goods produced at home can be used either for consumption net of imported consumption, for investment net of imported investment or for exports: $Y=C-C_{\text {imported }}+I-I_{\text {imported }}+E x$. Inserting this into the household budget yields $I+E X$ $C_{\text {imported }}-I_{\text {imported }}-\delta K-r D-S=0$ or $I-\delta K-r D-S=I m-E x$. This is the standard result that

\footnotetext{
${ }^{3}$ Irreversibility of capital is only a problem if the existing capital stock exceeds the optimal one by more than the rate of depreciation.
} 
(gross) investment minus (gross) savings equals the current account deficit. We assume goods market equilibrium to hold.

The transaction with other countries are goods trade, Ex-Im, paying interest on net foreign debt, $r D$, and incurring of new debt, $d D$. The balance of payments then is $d D=I m-E x+$ $r D$. Using the goods market equilibrium result we get $d D=I-S-\delta K$. In an open economy with capital mobility, the country then can finance domestic investment in excess of savings through the international capital market, which yields increase in the country's international indebtedness, as reflected in equation (3):

$$
\dot{D}=I-S-\delta K=\dot{K}-S
$$

Dots indicate the change in a variable per unit of time. The first formulation of (3) has gross investment minus gross savings, and the second has net investment minus net savings. Domestic savings is assumed to depend on the country's income net of foreign interest payments, with marginal propensity to save out of net national income equal to $s$ :

$$
S=s(Y-\delta K-r D)
$$

Combining equations (2)-(4) yields a differential equation for the change in the country's external debt per period. For constant interest and depreciation rats this has a special form:

$$
\dot{D}=g K(0) e^{g t}-s\left[Y(0) e^{g t}-\delta K(0) e^{g t}-r D\right]
$$

For a formal treatment of this differential equation we refer to appendix A. In the next section we provide a more intuitive explanation. Note that these debt dynamics are 
derived from the goods market equilibrium condition and therefore reflect only the 'fundamentals': investment and savings. But it has been derived using all budgets the sum of which is the balance of payments. Note that this model shares the dominance of capital movements over the impact of the trade balance with those of the KeynesMundell-Fleming model and its successors under high capital mobility, and the YaariBlanchard-Weil type, because we assume perfect capital movements and an exogenous rate of interest. This feature is not purely a typically neoclassical one. Moreover, in spite of the large debt/GDP ratio of the USA presented below, there are no indications that they have had any impact on the world market interest rates (see Lane and Milesi-Ferretti 2002, Fig.11). Otherwise our assumption of a given world market interest rate would not be justified. Below we provide some evidence.

\section{Debt cycle versus permanent debtor position}

First, we slightly rewrite equation (3'). From the marginal productivity condition (2), we see in case of a CES production function that $r+\delta=\beta(Y / K)^{(1-\rho)}$. Substitution for $Y(0)$ leads to:

$$
\dot{D}=K(0)\left[g+\delta s-s((r+\delta) / \beta)^{1 / 1-\rho}\right] e^{g t}+s r D
$$

Subsequently we express $D$ in terms of $G D P(Y)$. To this purpose, we first divide both sides of equation (3') by $D$, subtract $g$ - the steady-state growth rate of $Y$ - and then multiply by $D / Y{ }^{4}$ The result is as follows:

\footnotetext{
${ }^{4}$ Alternatively, we may express $D$ as a percentage of the stock of efficient labor $(A L)$. Equation (5) is unaltered by this transformation, apart from the definition of $d$, which would be $D / A L$. We prefer to use GDP as the denominator as both GDP and $D$ are generally available in US\$, whereas $A L$ is only available in real terms. Hyperinflationary periods make conversion much more problematic when $A L$ is used to normalize.
} 
$\dot{d}=\underline{k}\left[g+\delta s-s((r+\delta) / \beta)^{1 / 1-\rho}\right]-[g-s r] d$

$d$ denotes the ratio of debt over GDP $(D / Y)$. In equation (5), $\underline{\mathrm{k}}$ is the capital-output ratio corresponding to equation (2). The sign and size of the slope and the intercept depend on the (unobserved) parameters $g, s, \beta, \delta$, and $r$ and can be positive or negative. The three possible cases - corresponding to the different stable and unstable paths of the differential equations - are shown in figure 1 . In this figure, $d$ is on the horizontal axis, while $\dot{d}$ is on the vertical one. If interest and depreciation are not assumed to be constant, the first g-term has to be replaced by the growth rate of $K$ and the second by that of $Y$.

$$
\text { If } s((r+\delta) / \beta)^{1 /(1-\rho)}>g+\delta s>g>s r \text {, assuming }(r+\delta) / \beta<1 \text { and } \rho<0,{ }^{5} \text { both the slope and }
$$

the intercept are negative; the corresponding line in Figure 1 is indicated by $S C$. The stable stationary point (I) is at negative values of $d$, implying that the country becomes a creditor in the long run. In point $\mathrm{I}$, the ratio of foreign wealth $(D)$ to GDP is constant if there are no more shocks. Both $D$ and $Y$ grow at the same rate $g$. Since $D$ is negative, it implies the country holds positive net foreign assets in the steady state. Suppose the country starts out as a debtor at positive values of $d$. Subsequently, $d$ will decrease to converge to the steady state along line SC. It can be easily shown that initially the level of external debt $D$ will still grow - though at a slower pace than GDP - corresponding to a current account deficit. Over time, the current account deficit is reduced and turns into a surplus with reduction in $D$. This case is the traditional view on the debt cycle in which every country eventually becomes a creditor (non-debtor).

\section{FIGURE 1 ABOUT HERE}

If $g+\delta s>s((r+\delta) / \beta)^{1 /(1-\rho)}$, and $g>s r$, the slope remains negative, but the intercept becomes positive. This case is captured by line SD in figure 1 . Now, the country converges to a

\footnotetext{
${ }^{5}$ In case of a Cobb-Douglas function we have $\rho=0$ and $s(r+\delta) / \beta>s r$, with beta as the elasticity of production of capital. For the empirically relevant negative CES parameters with an elasticity of substitution smaller than unity, $-\infty<$ $\rho<0$ and assuming $(r+\delta) / \beta<1$, which seems empirically reasonable, we get $s(r+\delta / \beta)^{1 / 1-\rho}>s r$.
} 
steady state (II) where $d$ is positive. The economy remains a debtor because of its low savings ratio and/or the low world interest rate. The low savings rate forces the country to externally finance its domestic investment, while the low world interest rate helps to reduce the cost of doing so. In the steady state, $D$ again grows at the rate $g$, which implies that the country remains a capital importer. The current account is not balanced in the long run unless the horizontal intercept of the differential equation is at the origin. ${ }^{6}$

If $g$-sr $<0$, the slope is positive and the vertical intercept is negative for $\rho, \delta=0$ and values in their neighbourhood. This is the unstable case, labeled $U$ in figure 1. By implication, $g-$ $s r>0$ is a stability condition, but obviously, there is no reason to a priori impose a stability assumption. The stationary but unstable point (III) is at a positive value of $d$. If $d(0)$ is less than in the stationary point, the economy starts moving to the region of negative and continuously declining $d$. In that case, the country will be a creditor in the long run, where GNP grows faster than GDP. This was the point Amano (1965) tried to make.

A starting point to the right of the stationary point implies that $D(0)$ sufficiently exceeds $K(0)$ if $\rho, \delta=0$, as shown in appendix A. The country then starts out with more debt than capital and will have negative current wealth for all periods. Clearly this is unsustainable in the longer run. A country on such explosive path will be forced to adjust, one way or the other. ${ }^{7}$ As $D(0)>$ $K(0)$ seems to be an unrealistic case from an empirical point of view, we would interpret explosive debt dynamics as a case of non-sustainable economic policy when it appears in our estimates and as a temporary deviation from the assumptions of our model, which are those of a good debtor. $D(0)<K(0)$ can be reconciled with instability only if the elasticity of substitution is

\footnotetext{
${ }^{6}$ In the literature it is often assumed that the current account must be balanced in the long run, based on the assumption that creditors will try to increase their welfare by not allowing other countries to borrow permanently (see Cohen 1991). Whether this is the case, however, is an empirical as well as a theoretical question. In our model we do not explicitly impose the restriction of a balanced CA.

${ }^{7}$ Neher (1970) assumes that debt $d$ grows at the same rate as the capital stock. As we have shown, this is only the case in the steady states of the stable cases. Amano (1965) has treated only the left arm of the unstable case. Our model integrates all these cases.
} 
larger than unity (see appendix). Our estimate below does not support the empirical relevance of this case.

In this type of model, a switch from one dynamic process - say the SD line - to another say the SC line - can only arise due to changes in the underlying parameters of the system, $g, s, \beta$, and $r .^{8}$ As an example, we will discuss a non-anticipated and permanent upward jump in the world interest rate. If this happens, the marginal product of capital will increase and the optimal amount of capital $K$ to be used will fall. For a given national wealth $W$, a fall in the desired level of capital $K$ implies that less external debt $D$ is required. As a result less debt is obtained from the international capital market. Alternatively stated, it implies that more domestic wealth is invested abroad at the higher world interest rate level. Such a decrease in capital inflows or increase in capital outflow - even capital flight - thus can be rooted in the economy’s fundamentals and need not be a purely monetary phenomenon of irrational speculators. Domestically, the resulting lower marginal product of labor leads to a fall in real wages.

We can also describe these dynamics in terms of differential equation (5) and Figure 1. Starting from a situation where the country is a long-run debtor (the SD line) a jump in the interest rate leads to both a counter-clock wise rotation (flatter slope) and a downward shift of the SD line. The economy can move from the SD in figure 1 to a situation SC or even to a situation $U$, depending on the size of the interest rate shock.

A similar analysis can be given for other exogenous events changing the slope and intercept of the differential equation, like for instance a jump in the savings rate $s$ or in the rate of population growth $n$ or technical change which in turn changes $g$.

In the empirical part of our paper, we will present evidence on the extent to which the United States have switched between the different regimes of debt dynamics over the period 1960-2002. The empirical equivalent of equation (5) that we use in the first estimation is:

\footnotetext{
${ }^{8}$ Of course, there can also be exogenous shocks to $d$ without changing the prevailing differential equation. This moves the economy along the relevant line in figure 1 rather than changing the position of the line itself.
} 


$$
\dot{d}=\alpha_{0}+\alpha_{1} d(-1)
$$

with $\alpha_{0}=\underline{k}\left(g+\delta s-s((r+\delta) / \beta)^{1 / 1-\rho}\right), \alpha_{1}=s r$-g. Clearly, the regression coefficients are complex functions of behavioral parameters like the savings rate and exogenous but time-varying variables like the world interest rate. Without additional information on these parameters and variables, we can just report the regression estimates and account for potential time-variation. When more information is made below under additional assumptions, an extended regression of the model is possible. Note also that the explanatory variable in equation (6) is lagged one year. This is due to the switch from the continuous-time derivation of our theoretical model to the discrete-time formulation of the empirical model.

\section{Data, Estimation and results}

Cumulating the differences of gross investment and savings, starting from the net international investment position of 254.57 billion US dollars in 1980 according to IMF IFSY 2001, we get the values for cumulated debt $D$ in Appendix B. Savings is gross savings (GDP minus consumption) according to the World Development Indicators plus net current transfers plus net income from abroad in order to have it as disposable income minus consumption. We could get almost identical results from the accumulation of current account deficits. However, these deficits can be financed at times by reductions of reserves. This then would overestimate the new debt of the corresponding years. For the most recent years the cumulated debt calculated is identical but in other years there are deviations.

Dividing the cumulated debt by the value of the GDP we get the debt/GDP ratio. In Figure 2a we plot these data together with the Net international investment position (from Table 1) per unit of GDP. The values are identical in the beginning just by assumption. They are lower 
for later years but become equal again in 2001. With debt data from cumulated investmentsavings differences, cumulated current account data and NIIP being very similar in the beginning and in the end of the period considered and differing in between because of effects from exchange rate valuation to be discussed next, the consequences of imperfections in the calculations of savings do not seem to be overly important here.

\section{FIGURE 2 OVER HERE}

The difference between our data and the NIIP can be explained by the official exchange rates of the UK, Germany and Japan (local currency units per US\$ from World Development indicators 2004) indicating (at least partly) the valuation effects. The regression result with dependent variable (debt/GDP - NIIP/GDP) is ('tsq' is a squared time trend):

\begin{tabular}{lllll}
\hline & \multicolumn{5}{l}{ Standard } \\
& Coefficients & Error & $t$ Stat & $P$-value \\
\hline Intercept & 0.099596 & 0.045414 & 2.193057 & 0.041681 \\
Germany & -0.13543 & 0.061942 & -2.18646 & 0.042232 \\
United Kingdom & 0.345361 & 0.094013 & 3.673552 & 0.001738 \\
Japan & -0.00053 & 0.000276 & -1.90951 & 0.072266 \\
Tsq & -0.00016 & $4.03 \mathrm{E}-05$ & -4.03995 & 0.000768 \\
\hline
\end{tabular}

Adjusted R Square 0.843989382

All of the variables used here have a unit root. These variables are not cointegrated. Therefore we re-estimate the above equation in first differences getting the following result:

\begin{tabular}{|c|c|c|c|c|}
\hline \multicolumn{5}{|c|}{$\begin{array}{l}\text { Dependent Variable: D(DMINNIIP), Method: Least Squares } \\
\text { Sample (adjusted): } 1981 \text { 2002, Included observations: } 22 \text { after adjustments }\end{array}$} \\
\hline Variable & Coefficient & Std. Error & t-Statistic & Prob. \\
\hline C & -0.004729 & 0.004891 & -0.966849 & 0.3464 \\
\hline D(EGER) & -0.140701 & 0.067808 & -2.074976 & 0.0526 \\
\hline $\mathrm{D}(\mathrm{EJ})$ & -0.000540 & 0.000313 & -1.726158 & 0.1014 \\
\hline $\mathrm{D}(\mathrm{EUK})$ & 0.390266 & 0.139891 & 2.789789 & 0.0121 \\
\hline Adjusted R-squared & 0.383099 & \multicolumn{2}{|c|}{ Akaike info criterion } & -4.711 \\
\hline Schwarz criterion & -4.513375 & \multicolumn{2}{|c|}{ F-statistic } & 5.34703 \\
\hline Durbin-Watson stat & 2.297910 & \multicolumn{2}{|c|}{ Prob(F-statistic) } & 0.008236 \\
\hline
\end{tabular}

Results for first differences are very similar to those for levels. As the NIIP values are fluctuating and so are the exchange rate values (see Figure $2 \mathrm{~b}$ ), whereas our debt/GDP ratio data are fairly 
smooth, our data can be viewed as a version of NIIP data cleaned from fluctuations in the valuations. ${ }^{9}$ Note that only for the British pound do we get the expected sign of the valuation channel: an appreciation of the dollar (more pounds per dollar) should lead to a lower NIIP in dollars because US claim are to a large extent in other currencies (see Tille 2004) and a higher difference between our debt/GDP data and the NIIP. The negative sign for the YEN and the Euro is consistent with a dominance of the trade channel if an appreciation of the dollar worsens the current account and increases the difference between investment and savings and this has a stronger impact on our debt/GDP data than on the NIIP data. Our data capture what we expect to be continued steadily through the future because of the differences between savings and investments. It is much harder to have a clear cut expectation on the exchange rate valuations. A forecast therefore should be based on our data because they depend less on unpredictable valuations. $^{10}$

Using the debt/GDP variable we can run a regression indicated by equation (6). We use the least squares approach with the Newey-West HAC ${ }^{11}$.

\section{Long-run dynamics}

The result is summarized in Regression (1) of Table 3. According to this estimate the intercept is positive and we are in regime 'stable debtor' (SD) of Figure 1. The country would approach a constant debt/GDP ratio in the long run. The equation suffers from autocorrelation; adding an ARMA(1,1) process the error probability of rejecting the hypothesis of no autocorrelation is between $28 \%$ for 5 lagged residuals and $71 \%$ for 3 lagged residuals. ${ }^{12}$ Therefore we do not reject

\footnotetext{
${ }^{9}$ For Japan the regression uses data yen/\$ whereas figure $2 \mathrm{~b}$ uses $100 y e n /$ dollar.

${ }^{10}$ Readers particularly interested in portfolio and valuation effects on and from exchange rate movements are referred to Tille (2004), Roubini and Setser (2004) and Blanchard et al. (2005). We'll have a minor digression to the trade balance and devaluations below.

${ }^{11}$ HAC means 'heteroscedasticity and autocorrelation correction'. In our case using the routine in Eviews OLS gives about the same significance.

${ }^{12}$ According to econometric theory the least squares estimate is only unbiased if the 'true' residual of a period is not correlated with the independent variable of other or the same periods. However, adding lagged dependent variables as
} 
the hypothesis. Standard unit root tests indicate that the slope may be zero. The error probability of rejecting this hypothesis in an ADF test with a time trend is about 30\%. This would indicate that the differential equation is not even stabilized at high values. However, the time trend is highly insignificant. If we drop it, we can use the estimate to determine the coefficients of equation (6). The result is the third regression in Table 3. Although the lagged dependent variables are usually introduced in order to remove autocorrelation, the Breusch-Godfrey test tells us that they do not do this. Trying to add a quadratic regressor does not yield a significant result.

\section{TABLE 3 OVER HERE}

For the first, the second and the third regression the stationary value of the debt/GDP ratio will be $58.6 \%, 55.5 \%$ and $50 \%$ respectively. This implies that it might become about twice its 2002 value of .27 according to the estimated model. Of course, this will only happen if the world market interest rate is not driven up and there are no substantial spreads above LIBOR/EURIBOR coming up for the United States. Both of these effects might dampen the increase of the debt/GDP ratio. Nothing like that has been observed so far. Therefore they are not included in the model. If this does not happen the question is: How long does it take until the $50 \%$ level is reached?

\section{FIGURE 3 OVER HERE}

Making a dynamic forecast of all equations we find that the first regression is the best according to most of the forecast criteria, in particular the high covariance proportion and the zero bias proportion (see Figure 3). If we add exchange rates to this forecast we get a positive bias proportion (not shown), which again confirms that valuation effects have not much of an impact on our debt/GDP data. From the forecast for the debt/GDP ratio one finds that the USA will reach the $50 \%$ mark of a debt /GDP ratio by 2040. The forecast in Figure 3 has a Theil index of .026, which is very close to its ideal value of zero, which would indicate a perfect fit. The bias

instruments in a general method of moments estimate does not lead to confirmation of the additional restrictions in the standard chi-square test. 
proportion and the variance proportion of the mean squared error are almost zero and almost the whole error is in the unexplained part called covariance proportion. For the static one-period forecast the results are even better (not shown). In particular, the real development never is outside the margin of two standard deviations. The CUSUM and CUSUM of squares tests are passed at the $5 \%$ level. In the static forecast there are three observations indicating non-constancy of parameters and in the dynamic forecast only one. All of these forecast properties indicate a quite good estimation result. The results for the change in the debt/GDP ratio in the lower part of figure 3 are slightly worse but the bias proportion is zero here.

FIGURE 4 OVER HERE

\section{TABLE 4 OVER HERE}

\section{Short-run deviations}

In order to detect short-run problems we run 7-years rolling windows regressions. The results are summarized in Table 4 and Figure 4. When the slope is positive in the period beginning in 1973 the USA is not even a debtor. The trade balance does not even dis-improve. But the interest rate increases in the period 1972-74 by 5.5\% (see IMF, International Financial Statistics Yearbook, 2000). For the 7-years periods beginning in 1979-82 we also find positive slopes. Although the USA are still a net creditor, the combination of restrictive monetary and expansive fiscal policy drives up the interest rate and attracts much foreign debt leading to a net debtor position in 1985 according to our data. Since 1983 it is broadly recognized that the dollar is overvalued and will have to depreciate. This happens in 1985. The stock market crashes in 1987. Our method signals increasing or positive slopes for the 7-years periods beginning 1976-1982 (ending 1984-88), that is warnings are available since 1982 or 1983 when the data become available. Our method would have warned against financial instability in the sense of an unstable differential equation of the debt/GDP ratio through devaluation of the dollar - and as a consequence a possible downturn of the stock exchange. Moreover, we find a positive slope for the periods beginning in 1988-91 (ending 1994-1997). In this period there is a recession in 1991 and an increase of the interest rate 
by 2.5 percentage points in the period 1993-1995. The positive slope with observations of the data corresponding to the upper right quadrant of Figure 1 suggests that the USA stop being a good creditor in this phase. After these periods the interest rates are decreasing again, production increases and the slope coefficients are going down again. Finally, for the last three intervals beginning 1993-95 and ending 1999-2002 we get again a positive coefficient at an order of magnitude that is similar to those before 1987.

Does all this imply that there is no problem? Not completely so: The fact that the United States did become a net debtor around 1985 according to our data and in 1989 according to the financial data may have long-term consequences. The increase in the debt/GDP ratio cannot go on forever at a constant rate. Our model indicates the problem: According to the long-run trend there is a decrease in the growth rate of the debt/GDP ratio; but current or future trends or economic policy can follow a path with an increasing growth rate of the debt/GDP ratio as in the periods beginning 1979-1982 (ending 1986-1988)) and intervals beginning 1993-95 and ending 1999-2002 or even going beyond it.

\section{Time-varying coefficients}

What's the risk that the United States move into the direction of explosive debt? The slope coefficients in Figure 4 suggest that the slope may be a time-varying parameter. Therefore we apply the state-space technique in order to get time-dependent slope and intercept values (see Hamilton 1994, section 2.6). ${ }^{13}$ The model (in eviews language) is as follows:

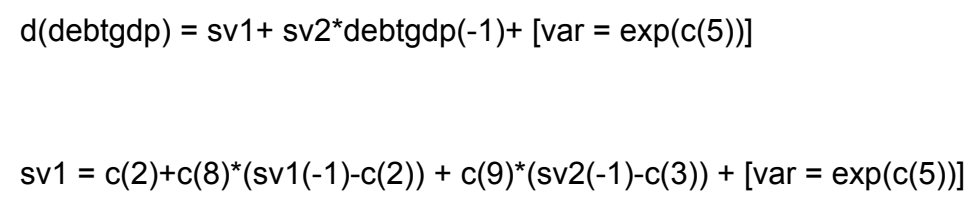

\footnotetext{
${ }^{13}$ We did not find any good result for Markov regime switching model in which a stable debtor and an unstable debtor would be the two regimes. This might change if there are more observations through the use of quarterly data.
} 
$\mathrm{sv2}=\mathrm{c}(3)+c(10)^{*}(\operatorname{sv} 1(-1)-c(2))+c(11)^{*}(\operatorname{sv} 2(-1)-c(3))+[\operatorname{var}=\exp (c(5))]$

Here sv1 is the intercept of the debt equation (6) and sv2 is the slope. The first equation reproduces the debt equation. The second and third equations are a difference equation system in the slope and intercepts coefficients in equation (6). c(2) is the average or steady-state value of all intercept estimates and c(3) is the average or steady-state value of all slope estimates. The values of the intercept and the slope depend on their previous values and are assumed to change in a way indicated by the coefficients $c(8)-c(11)$. The coefficients $c(i)$ are estimated. We assume that all equations have an error term and that their variance is identical. We did try to estimate with different variances, and also without error terms in the second and third equation. Results were much worse than in the above case.

\section{TABLE 5 OVER HERE}

The estimation output and the details of its analysis can be found in Table 5 and Appendix $C^{14}$ (see working paper version). It is shown there that the system has a stable focus. The coefficients c(9) and c(11), both for the time-varying slope parameter, are highly insignificant. An F-test shows that they can be dropped. The second regression then has $c(8)=.52$ and $c(10)=2.11$. As this means that sv2 is dropped from the right-hand side of the system it is obvious from looking at the system that the equation of sv1 is a stable one, which is not influenced by that for sv2, but rather is determining the change of sv2. It is a stable node. The implied absence of cyclical movements is unable to explain the ups and downs in the rolling windows regressions. Therefore it may be better not to drop c(9). If only c(11) is dropped from the first regression, in the third regression c(9) has a marginal significance level of almost 19\% and the result is a negative trace, a positive determinant and complex roots again. Again we get a stable focus and coefficients converging to their steady state in a spiraling path, which resembles those of the rolling windows regressions. Results for the one-period-ahead prediction of intercept, sv1, and the slope, sv2, are

\footnotetext{
${ }^{14}$ We found only one good result. Results obtained depend strongly on the initial values. However, all bad results we looked at were qualitatively the same in the sense that never any positive prediction for beta appeared.
} 
presented in Figure 5. The intercept varies around 2\% and the slope around $-4 \%$. Interestingly, positive slopes as they did appear in the rolling windows are never predicted. Probably, this is due to the fact that the estimates take on board the information of the good times of the sixties and seventies and therefore give relatively little weight to the periods where we found positive slopes for the rolling windows. The average values and the steady-state values for the intercept and slope are about as large as the estimates of the least squares equations. The system converges to its long-run steady-state value $a=s v 1-c(2)=0$ and $b=s v 2-c(3)=0$. The prediction for the long run then is $\mathrm{d} d=0.020596-0.036434 d$, which yields a steady state value of $d^{*}=0.565$, and similarly so for the other two regressions in Table 5. This is in the higher end of the range for the regressions of Table 3. But there is no instability problem.

\section{FIGURE 5 OVER HERE}

Much recent literature is interested the development of the trade balance. The balance-of payments equation for this model can be written as stated before equation (3):

$$
\dot{D}=T D+r D, \quad \text { or }, \dot{d}=T D / Y-(\hat{Y}-r) d
$$

$T D$ indicates the trade deficit. The second version has been obtained by dividing the first by $D$, subtracting the growth rate of $Y$ and multiplying by $d=D / Y$. Equating it with (6') and solving for the trade deficit yields

$$
T D / Y=(\hat{Y}-r) d+\alpha_{0}+\alpha_{1} d(-1)
$$

Under the additional assumption of a growth rate equal to the interest rate, the trade deficit as a share of the GDP equals the change in the debt/GDP ratio as forecasted in the lower part of Figure 3. This predicts a soft landing for the trade deficit going to zero because of the absence of financial problems in the model. If the interest rate is larger than the growth rate of the GDP as is the assumption in much of economic theory, trade deficits have to be even lower or, alternatively, can be higher during bubbles where the opposite case applies. If the whole adjustment of the trade balance for the benchmark case has to be achieved by a devaluation of the real exchange rate and 
this requires a devaluation of $7-10 \%$ for each percent of $T D / Y$ starting at $5 \%$ in 2004 and going to .005 in 2025 as predicted in figure 3, this requires a real devaluation of 30-45\% during the next 20 years, which is roughly one or two percent a year. If we do this consideration using the timevarying parameter system parameter constancy is achieved in 2025 but the fluctuations are very weak. The usual caveats for forecasts apply. In particular, if foreign financial investors expect this real devaluation to appear in the form of the nominal devaluation of the dollar they may want to reduce their financial position in the USA according the scenario by Roubini and Setser (2004) and the nominal devaluation may be quicker than the real one predicted above for the soft-landing scenario. However, as they know that they cause a lower valuation of their own assets they may want to do this only softly.

\section{Extension of the basic regressions}

Next, we will estimate the complete model for three reasons. First, when we did the previous regressions also with data available only until the year 1999, the predicted long-term debt/GDP ratio was a bit smaller. The last three years therefore seem to have a strong impact. This indicates that our procedure does not yield stable results, possibly because it does not take on board all relevant variables. Second, fluctuations in the slope and intercepts suggest that some of the variables contained in the intercept and slope have some variation. Third, some of the empirical work presented so far could also have been done from the perspective of an autoregressive process in the debt/GDP ratio without any theory. Therefore we should test in how far the model is not just a camouflage for an autoregressive process but rather yields reasonable estimates.

For purposes of regression analysis more information is obtained when leaving the marginal productivity condition as a separate equation. The model then consists of the equation for debt dynamics, the marginal productivity condition for capital (we do not use one for the labour market) and the production function. We take the first two in log form: 


$$
\begin{gathered}
\dot{d}+s(1-r d(-1)-\delta K(-1) / Y)=c(1)+c(2) * K(-1) / Y-c(3) * d(-1) \\
\log (K(-1) / Y)=(\log (r+\delta)-\log \beta) /(-1+\rho) \\
\log Y=(1 / \rho) \log \left[\beta K(-1)^{\rho}+(1-\beta)\left(A_{0} e^{b t} L\right)^{\rho}\right]
\end{gathered}
$$

The first equation is obtained by writing the version of equation (3) using net-expressions in discrete form, dividing by $D(t-1)$, subtracting the growth rate of GDP, multiplying by $d(-1)$, and taking some terms to the left-hand side. Then, $c(1)$ should be zero as it has been added only for econometric reasons. $c(2)$ should equal the growth rate of $K$, and $c(3)$ should equal $1-Y(t-1) / Y(t)$, which is approximately the growth rate of GDP. All terms on the left-hand side of the first equation are taken in the form of data, which means in particular that we deviate from the model by assuming no longer that the rates of saving, depreciation and interest and the capital-output ratio are given constants.

\section{FIGURE 6 OVER HERE}

\section{Additional Data}

In order to get the output variable, we divide the GDP in current US dollars by the GDP deflator as obtained from the NIPA data of the BEA. ${ }^{15}$ We deflate current gross fixed capital formation using the fixed investment deflator, cumulate it according to $K(t)=K(t-1)+I(t)-\delta(t) K(t-1)$. The rate of depreciation needed for this is obtained by division of data for nominal depreciation by a nominal capital stock. The latter is obtained by cumulating nominal gross fixed capital formation minus the nominal depreciation data with a starting value of gross fixed capital formation divided by an assumed depreciation rate of $5 \%$ of capital and an initial growth rate of $.048 .{ }^{16}$ Employment is taken in thousands of workers. Interest rates are the average of the last two columns of Table 1 minus the rate of GDP inflation. The savings rate is calculated as Gross national savings minus

\footnotetext{
${ }^{15}$ NIPA and BEA stand for 'National Income and Product Accounts' of the 'Bureau of Economic Analysis'. Data from this section are from this source unless stated otherwise.

${ }^{16}$ This value is obtained form a simple growth accounting exercise assuming a Cobb-Douglas function with a production elasticity of capital of $1 / 3$ and labour $2 / 3$, employment growth of .02 , technical change of .017, nominal GDP growth of 5.5 percent, GDP inflation of .014 and fixed investment inflation of .0054 .
} 
depreciation both in current dollars divided by (nominal net national income minus depreciation). Some of these data are plotted in Figure 6. A remarkable trend is the fall in the savings ratio since the early 1980s, where also the much discussed wage inequality process started. ${ }^{17}$ The interest rates are fairly low and again they fall during the period where debt/GDP ratio increases. In particular, we would have preferred to subtract investment income debit from investment income credit and divide it by the debt variable from Appendix A. However, when the USA goes from a creditor to a debtor position, interest rates calculated in this way move above $60 \%$ due to the effect of the denominator crossing zero. In other periods the difference often is negative and would have resulted in a negative nominal interest rate for all years in which the USA were a debtor already. This comes from the revaluation of the US claims which are held in EURO (see Cavallo 2004). Again this does not provide any indication of interest rates driven up by net foreign US debt.

\section{Econometric method and results}

In related literature that is close to the model used, imperfect capital mobility is captured by the assumption that the interest rate depends positively on the debt incurred per unit of GDP (see Bardhan 1967). In order to test the perfect capital mobility assumption for our data, we find that a vector autoregressive (VAR) model for the interest rate and the debt/GDP ratio has one lag according to the Schwarz criterion and three lags according the Hannan-Quinn criterion. The Johansen cointegration test shows cointegration for the period from 1983 onwards for both cases. In both cases the estimate of a VECM shows the wrong sign. Therefore there is no evidence that the debt/GDP ratio has an impact on the real interest rate (see Appendix D for the last two regressions), which justifies our assumption of perfect capital movements. Of course, this can

\footnotetext{
${ }^{17}$ For a trace to literature on the explanation of the falling savings ratio see Chanda (2005). As the savings ratio is taken to be exogenous we do not report the explanation of the fall.
} 
only be a very preliminary test but adding other countries debt/GDP ratios or other variables is beyond the scope of this paper.

Unlike the simplified model in section 3 there is a negative trend in the interest rate since the 1980s and a positive trend in the capital-output ratio at a rate smaller than one percent. Real interest rates follow inflation and are negative at least before 1979. Therefore we start the regression only in 1983, when inflation has come down to a value below 4\%. A second reason for this starting period is the information that capital mobility was increasing strongly after 1980 (see Obstfeld and Taylor 2002). ${ }^{18}$ The regression output is presented in Table 6 and Appendix E (see working paper version). The system is estimated using the general method of moments with heteroscedasticity and autocorrelation correction for the standard deviations t-value and p-values (GMM-HAC), because this takes on board dependence among the residuals of the equations and allows for the use of instruments in order to correct for endogeneity. Table 6 contains three versions of the regression.

\section{TABLE 6 OVER HERE}

The first regression does not use instruments in addition to the regressors and does not make any correction for the potentially existing autocorrelation bias. It is essentially a non-linear least squares estimate with constraints relating the second and third equation. The coefficients for the capital-output ratio and the debt/GDP ratio in the first equation have been restricted to equal each other as they would in the steady state of the model. $c(2)$ is about $5 \%$, which is a bit higher than one would expect in a steady state. The result $\beta=.34$ is about what one would also expect in case of a Cobb-Douglas function for the production elasticity of capital. The CES parameter has a value of $\rho=-1.85$, which implies an elasticity of substitution of $1 / 2.85$. The level of labour augmenting productivity as of $1959(t=0)$ is $c(11)=321$ per worker. The rate of labouraugmenting technical change is about $1.5 \%=c(12)$. As the model has five restrictions on the

\footnotetext{
${ }^{18}$ The classical counter-argument comes from the Feldstein-Horioka cross-country regressions of investment and savings for data before 1975. For recent evidence of high capital mobility based on modern econometrics see Hoffmann (2004), Coakley et al. (2004) and Fattouh (2005).
} 
coefficients the J-statistic goes away from the value of zero, which it would have when only regressors are used as instruments and there were no constraints (see Greene 2003, 548-9). The adjusted R-squared is remarkably low for the first equation and the Durbin-Watson indicates autocorrelation. It should be noted here that in the second equation the sum of interest and depreciation as well as the capital variable have unit roots according to a standard augmented Dickey-Fuller test. They are not cointegrated. Basic econometric theory would suggest estimating in first-differences. However, if we would do so, the intercept would drop out of the equation and this implies a loss of important information because the parameters appear also in the third equation and the corresponding constraint would therefore vanish as well. Sticking to the model then implies sticking to levels in the estimation. Similarly, in the third equation output and capital have unit roots, but employment does not. Therefore we estimate an unbalanced equation, which is controversial in itself (see Maddala and Kim 1998, 252-2). However, again sticking to the model is our preference.

In the second regression of Table 6 we have added lagged dependent variables as instruments in order to correct for endogeneity. Table 6 indicates that the number of instruments in addition to the regressors is six, zero and three respectively. In the first equation the capital/output and the debt/GDP ratio are endogenous. As these are cumulative variables, we would want to add many lagged instruments. It is possible to add three lags. The second equation has only the real interest and depreciation rate as a regressor, which we consider to be exogenous. Therefore no instruments are used here except for the regressors. The third equation has only the capital variable as endogenous regressor. We can add three lags as instruments. The major impact of the use of instruments is in the t-values. All other results change only marginally. The elasticity of substitution is now $1 / 3$. The J-statistic increases only marginally and the product of the number of observations and the J-statistic is clearly below the chi-square value (not shown), which justifies our number of instruments. 
In the third regression we have followed one of the standard advices in regard to autocorrelation that is to add lagged dependent variables (the other advice is “don't”' (see Greene 2003) and stay with the second regression). For the debt equation and the marginal productivity equation we have employed lagged dependent variables as autocorrelation correction. In particular it was not possible to add lagged dependent variables to the third equation. As the lagged dependent variables are also endogenous regressors now, we have also added them to the instruments. The Durbin-Watson statistic for the production function and the marginal productivity condition still indicate high autocorrelation. Adjusted R-squares and marginal significance levels are fairly good. The only exception is the intercept, which should be zero according to the theoretical model; it is indeed highly insignificant. The other major change coming from this autocorrelation correction is that the parameters of the CES function have become much smaller and therefore the elasticity of substitution is much lower than before, $1 / 6.45$. The rate of labour-augmenting growth goes to $1.65 \%$ which is fairly close to the famous 1.7\% mentioned by Mankiw, Romer, Weil (1992). The level of labour-productivity is 350, which means that a worker is 350 times more productive than his counterpart in a hypothetical country that has never had any technical change. These numbers are compatible with the fact that people in developed countries are several hundred times richer than those in the poorest countries. Under the additional assumption that the rate of technical change has always been $1.65 \%(1.5 \%)$, technical progress must have started about 427 (398) years ago (from 2002), that is slightly after $1575(1600){ }^{19}$

The autocorrelation correction reduces residuals (see plot in Appendix F in the working paper version) by $50 \%$ in the first two equations. It is obvious that it mirrors the business cycle deviations from the growth model. For example in the 1991 recession, the residuals are negative for the GDP, positive for the capital-output ratio and negative for the change of the debt/GDP

\footnotetext{
${ }^{19}$ Kremer (1993) has a nice description of world wide technical change phenomena of earlier times with a rate of technical change below .3\% though for the world as a whole before 1600 .
} 
ratio, the latter result reflecting that investment tends to go back during recessions and more so than GDP.

It is hard to decide, whether or not the third regression is more convincing than the second. A decision will depend on the readers view concerning autocorrelation correction. The values of the estimates are quite reasonable values in both cases, with the expected signs and high significance. This may justify our feeling that the model is a reasonable choice for the USA in the period in question.

\section{Summary and Conclusion}

In this paper we have analyzed the dynamics of US foreign debt from the perspective of the central differential equation of the neoclassical growth model with perfect capital movements and a CES production function. Our preliminary test shows that US debt does not drive up the interest rate and therefore may justify the assumption of perfect capital movements.

The US debt/GDP ratio is increasing. Our concept reveals that it is of utmost importance whether this happens at an increasing or a decreasing growth rate, because this is the difference between the stable and the unstable cases of the model.

We construct debt data from the accumulated differences of investment and savings, the problem that is likely to continue, and show that the difference between our data and the NIIP data can be largely explained by exchange rate movements, which are hard to predict.

We find that the long-run debt dynamics can be characterized by a decrease in the growth rate of the debt/GDP ratio, which leads to a stable value of the latter in the long run in the range of $50 \%$ and $60 \%$, depending on the details of the methods. Using the simple OLS regression for a forecast, the debt/GDP ratio will reach a value of 50\% under the linear specification at about 2040 and then approach its steady state value of about 58\%. A savings ratio, which is lower in the second half of the period under consideration, seems to be the major 'culprit'. 
In the short run, however, there are phases where the long-run path is left and debt becomes explosive for short periods. The unstable phases happen to occur when economic policy drives up interest rates. These phases are likely to be followed by devaluations of the dollar. The United States will have to make sure that they have low interest rates and exchange rates and a high growth rate. Increasing government deficits are not a contribution to this aim.

Given the great variability of the slope coefficients for the differential equation in the debt/GDP ratio we have also estimated time-varying parameters. The law of motion for the timevarying parameters shows that there is no instability and the intercept and the slope converge to their long-run average values with a debt/GDP ratio of about $56 \%$.

The trade balance is predicted to go towards zero in the long run. Going from $5 \%$ to .5 percent until 2025 requires real devaluations of 30-45\%.

The analysis with time-varying parameters would suggest that there is no problem in the debt dynamics. However, this may be due to the fact that the method used takes the past strongly into account. If there is really a structural break the warning from the rolling window method may be more informative because it drops all information that is backward more than, in our case, 7 years.

We have estimated the neoclassical growth model with perfect capital movements - a CES production function and a marginal productivity condition for capital jointly with the debt dynamics - and find the expected signs of the coefficients at least at the five percent significance level. For the USA in the time period in question the model seems to be reasonably good for the question treated. Results for the level and growth rate of labour-augmenting technical change are 350 and $1.65 \%$ respectively.

Finally, it might be useful to think of possible reasons for overthrowing our prediction. According to our model differences between investment and savings drive the debt process, and this in turn would determine the trade balance. If the debt accumulation though would generate expectations of devaluations, the expected valuation effects might lead to a withdrawal of foreign 
capital. This type of self-fulfilling prophecy is not taken into account in our model because in general it can go also the other way around. However, it may not last very long and the economy may return to the predicted path. A more critical question therefore might be what the future values of savings ratios and interest rates will be. This seems to be most difficult to forecast and is the subject of several areas of research but goes beyond this paper. 


\section{References}

Amano, A. (1965), International Capital Movements and Economic Growth, Kyklos, 693-699.

Bardhan, P.K. (1967), Optimum Foreign Borrowing, in: Essays in the Theory of Optimal Growth, edited by K. Shell, 117-128, MIT Press, Cambridge.

Blanchard, O., F. Giavazzi, F. Sa (2005), The U.S. Current Account and the Dollar, NBER Working paper 11137, February.

Cavallo, M. (2004), Exchange Rate Movements and the U.S. International Balance Sheet, FRBSF Economic Letter, Number 2004-25, September 10.

Chanda, A. (2005), The Rise in Returns to Education and the Decline in Household Savings. mimeo, February.

Chiang, A.C. (1984), Fundamental Methods of Mathematical Economics, McGraw-Hill, $3^{\text {rd }}$ ed., Singapore.

Coakley, J., A.M. Fuertes, F. Spagnolo (2004), Is the Feldstein-Horioka Puzzle History? The Manchester School Vol.72 No.5, 569-590.

Cohen, D. (1991), Private Lending to Sovereign States: A Theoretical Autopsy, MIT Press Cambridge, Massachusetts, London, England.

Fattouh, B. (2005), Capital Mobility and sustainability: Evidence from U.S current account data, Empirical Economics30, 245-253.

Greene, W.H. (2003), Econometric Analysis, $5^{\text {th }}$ edition, Prentice-Hall Pearson, New Jersey.

Hamilton, J.D. (1994), State-Space Models. In: R.Engle and D. McFadden (eds.), Handbook of Econometrics, vol.4, 3039-3080.

Hoffmann, M. (2004), International capital mobility in the long run and the short run: can we still learn from saving-investment data? Journal of International Money and Finance 23, 113131.

IMF (2004, 2001), International Financial Statistics Yearbook, Washington.

Kremer, M. (1993), Population Growth and Technological Change: One Million B.C. to 1990, Quarterly Journal of Economics, August, Vol. 108, Iss.3, 681-716.

Lane, P.R. and G.M. Milesi-Ferretti (2001), The external wealth of nations: measures of foreign assets and liabilities for industrial and developing countries, Journal of International Economics 55, 263-294.

Lane, P.R. and G.M. Milesi-Ferretti (2002), Long-Term Capital Movements, NBER Macroeconomics Annual, MIT Press , Cambridge MA.

Maddala, G.S. and In-Moo and Kim (1998), Unit roots, Cointegration, and Structural Change, Cambridge University Press.

Mankiw, N.G., D. Romer, D.N.Weil (1992), A Contribution to the Empirics of Economic Growth, The Quarterly Journal of Economics, May.

Neher, P.A. (1970), International Capital Movements along Balanced Growth Paths, The Economic Record, September, 393-401.

Obstfeld, M. and A.M. Taylor (2002), Globalization and Capital Markets, NBER WP 8846, March.

Roubini, N. and B. Setser (2004), The US as a Net Debtor: The Sustainability of the US External Imbalances, mimeo, November.

Tille, C. (2003), The Impact of Exchange Rate Movements on U.S. Foreign Debt, in: Current Issues in Economics and Finance, Federal Reserve Bank of New York, Vol.9, No.1, January.

Tille, C. (2004), Financial integration and the Wealth Effect of Exchange Rate Fluctuations, mimeo, August. 
World Bank (2004), World Development Indicators, Washington.

\section{Appendix A: Solution of the differential equation}

The differential equation has the solution

$D(t)=D(0) e^{s r t}+K(0) B\left(e^{g t}-e^{s r t}\right)$

with $B \equiv\left(g+\delta s-s((r+\delta) / \beta)^{1 /(1-\rho)}\right) /(g-s r)$. In the long run the larger of the two growth rates will dominate the process:

$\lim D(t)_{t \rightarrow \infty}=$

$e^{g t} K(0) B=K(t) B \quad$ if $\quad g-s r>0$, or $\quad e^{s r t}[D(0)-K(0) B] \quad$ if $\quad g-s r<0$

As $s[(r+\delta) / \beta]^{1 /(1-\rho)}>s r$ for $\rho<0$ as assumed here, we can distinguish the four cases of Figure 1 . An unstable case with exploding debt/GDP ratio would require $s r>g$ and $D(0)-K(0) B>0$. For $\delta$ and $\rho$ both close enough or equal to zero we would have $B>1$ and therefore $D(0)>>K(0)$ would be required. This case is fairly unrealistic because it implies that the country has negative current wealth from the beginning and through eternal times while we see from the data that all countries have positive savings at almost all times with only very short periods of exceptions.

The more general case is more complicated. Combining g-s $<0$ and $\mathrm{B}<1$ in order to allow for $D(0)<K(0)$ requires $\rho>1$, which means that substitution goes the wrong way, or the elasticity of substitution is larger than unity. This can be shown as follows:

$B \equiv\left(g+\delta s-s((r+\delta) / \beta)^{1 /(-\rho)}\right) /(g-s r)<1$, with $g-s r<0$ implies

$g+\delta s-s((r+\delta) / \beta)^{1 /(1-\rho)}>g-s r ;$ cancelling and switching terms to the other side yields:

$(r+\delta)_{s}>s((r+\delta) / \beta)^{1 /(1-\rho)} ;$ canceling $s$ and taking natural logs on both sides yields

$\ln (r+\delta)>[1 /(1-\rho)] \ln ((r+\delta) / \beta)$

As the case $1-\rho<0$ takes substitution the wrong way, we assume1- $\rho>0$. Multiplication by (1- $\rho)$ then yields

$(1-\rho) \ln (r+\delta)>\ln (r+\delta)-\ln \beta$ or $-\rho \ln (r+\delta)>-\ln \beta$

Case 1: As the log expressions are negative, a negative $\rho$ leads to a negative left-hand side and a positive right-hand side and therefore the larger sign cannot hold and we have a contradiction. Therefore a negative $\rho$ has to be ruled out.

Case 2: Suppose $(r+\delta)<\beta<1$ and therefore $\ln (r+\delta)<\ln \beta<0$ and $\ln (r+\delta)>-\ln \beta>0$, a value of $\rho$ slightly below unity yields a result free of contradiction. But it implies an elasticity of substitution larger than unity.

Case 3: If $(r+\delta)>\beta>0, \ln (r+\delta)>\ln \beta,-\ln (r+\delta)<-\ln \beta$. The condition A.3 still requires a positive $\rho$ larger than unity to turn the sign around into that of A.3, and substitution goes again the wrong way. 


\begin{tabular}{|c|c|c|c|c|}
\hline \multicolumn{5}{|c|}{ Appendix B: Data } \\
\hline United States & $\mathrm{dD}=\mathrm{I}-\mathrm{S}$ & D & GDP & debt/gdp ratio \\
\hline 1960 & 509020000 & $-4.24 \mathrm{E}+11$ & $5.2012 \mathrm{E}+11$ & $-8.16 \mathrm{E}-01$ \\
\hline 1961 & -369305000 & $-4.25 E+11$ & $5.3811 \mathrm{E}+11$ & $-7.89 \mathrm{E}-01$ \\
\hline 1962 & 421020000 & $-4.24 \mathrm{E}+11$ & $5.7887 E+11$ & $-7.33 \mathrm{E}-01$ \\
\hline 1963 & -663410000 & $-4.25 E+11$ & $6.1068 \mathrm{E}+11$ & $-6.96 \mathrm{E}-01$ \\
\hline 1964 & -2883380000 & $-4.28 \mathrm{E}+11$ & $6.5632 E+11$ & $-6.52 E-01$ \\
\hline 1965 & -1067600000 & $-4.29 E+11$ & $7.1243 \mathrm{E}+11$ & $-6.02 \mathrm{E}-01$ \\
\hline 1966 & 1718050000 & $-4.27 E+11$ & $7.8114 \mathrm{E}+11$ & $-5.47 \mathrm{E}-01$ \\
\hline 1967 & 2337571000 & $-4.25 E+11$ & $8.2546 \mathrm{E}+11$ & $-5.15 \mathrm{E}-01$ \\
\hline 1968 & 4862434673 & $-4.20 E+11$ & $9.019 E+11$ & $-4.66 \mathrm{E}-01$ \\
\hline 1969 & 5161860000 & $-4.15 E+11$ & $9.7386 \mathrm{E}+11$ & $-4.26 \mathrm{E}-01$ \\
\hline 1970 & 3300000000 & $-4.12 E+11$ & $1.0255 E+12$ & $-4.01 \mathrm{E}-01$ \\
\hline 1971 & 11000100000 & $-4.01 E+11$ & $1.114 \mathrm{E}+12$ & $-3.60 \mathrm{E}-01$ \\
\hline 1972 & 12600000000 & $-3.88 E+11$ & $1.2247 \mathrm{E}+12$ & $-3.17 \mathrm{E}-01$ \\
\hline 1973 & -600000000 & $-3.89 E+11$ & $1.3693 \mathrm{E}+12$ & $-2.84 \mathrm{E}-01$ \\
\hline 1974 & 3100000000 & $-3.85 E+11$ & $1.4844 \mathrm{E}+12$ & $-2.60 \mathrm{E}-01$ \\
\hline 1975 & -3600100000 & $-3.89 E+11$ & $1.6178 \mathrm{E}+12$ & $-2.40 \mathrm{E}-01$ \\
\hline 1976 & 15900100000 & $-3.73 E+11$ & $1.8053 E+12$ & $-2.07 \mathrm{E}-01$ \\
\hline 1977 & 30799900000 & $-3.42 E+11$ & $2.0117 E+12$ & $-1.70 \mathrm{E}-01$ \\
\hline 1978 & 31100000000 & $-3.11 \mathrm{E}+11$ & $2.2749 \mathrm{E}+12$ & $-1.37 \mathrm{E}-01$ \\
\hline 1979 & 33900000000 & $-2.77 E+11$ & $2.5444 \mathrm{E}+12$ & $-1.09 \mathrm{E}-01$ \\
\hline 1980 & 22799800000 & $-2.55 E+11$ & $2.7715 E+12$ & $-9.19 E-02$ \\
\hline 1981 & 21200200000 & $-2.33 E+11$ & $3.1045 \mathrm{E}+12$ & $-7.52 \mathrm{E}-02$ \\
\hline 1982 & 3200000000 & $-2.30 E+11$ & $3.2286 \mathrm{E}+12$ & $-7.13 E-02$ \\
\hline 1983 & 79100000000 & $-1.51 \mathrm{E}+11$ & $3.502 E+12$ & $-4.31 \mathrm{E}-02$ \\
\hline 1984 & $1.056 \mathrm{E}+11$ & $-4.55 \mathrm{E}+10$ & $3.8966 \mathrm{E}+12$ & $-1.17 \mathrm{E}-02$ \\
\hline 1985 & $1.228 \mathrm{E}+11$ & $7.73 E+10$ & $4.1749 \mathrm{E}+12$ & 1.85E-02 \\
\hline 1986 & $1.847 \mathrm{E}+11$ & $2.62 E+11$ & $4.4118 \mathrm{E}+12$ & $5.94 \mathrm{E}-02$ \\
\hline 1987 & $1.554 \mathrm{E}+11$ & $4.17 \mathrm{E}+11$ & $4.6989 \mathrm{E}+12$ & $8.88 \mathrm{E}-02$ \\
\hline 1988 & 70900000000 & $4.88 \mathrm{E}+11$ & $5.0619 \mathrm{E}+12$ & $9.65 \mathrm{E}-02$ \\
\hline 1989 & $1.03 \mathrm{E}+11$ & $5.91 \mathrm{E}+11$ & $5.4397 \mathrm{E}+12$ & $1.09 \mathrm{E}-01$ \\
\hline 1990 & 99700200000 & $6.91 \mathrm{E}+11$ & $5.7508 \mathrm{E}+12$ & $1.20 \mathrm{E}-01$ \\
\hline 1991 & 4800300000 & $6.96 \mathrm{E}+11$ & $5.9307 \mathrm{E}+12$ & 1.17E-01 \\
\hline 1992 & 82101000000 & $7.78 \mathrm{E}+11$ & $6.2618 \mathrm{E}+12$ & $1.24 \mathrm{E}-01$ \\
\hline 1993 & $1.368 \mathrm{E}+11$ & $9.15 \mathrm{E}+11$ & $6.5829 \mathrm{E}+12$ & $1.39 \mathrm{E}-01$ \\
\hline 1994 & $1.666 \mathrm{E}+11$ & $1.08 \mathrm{E}+12$ & $6.9933 \mathrm{E}+12$ & $1.55 \mathrm{E}-01$ \\
\hline 1995 & $1.245 \mathrm{E}+11$ & $1.21 \mathrm{E}+12$ & $7.3384 \mathrm{E}+12$ & $1.64 \mathrm{E}-01$ \\
\hline 1996 & $1.438 \mathrm{E}+11$ & $1.35 \mathrm{E}+12$ & $7.7511 \mathrm{E}+12$ & $1.74 \mathrm{E}-01$ \\
\hline 1997 & $1.528 \mathrm{E}+11$ & $1.50 \mathrm{E}+12$ & $8.2565 E+12$ & $1.82 \mathrm{E}-01$ \\
\hline 1998 & $1.689 \mathrm{E}+11$ & $1.67 \mathrm{E}+12$ & $8.7202 \mathrm{E}+12$ & $1.92 \mathrm{E}-01$ \\
\hline 1999 & $2.373 E+11$ & $1.91 \mathrm{E}+12$ & $9.2128 \mathrm{E}+12$ & $2.07 \mathrm{E}-01$ \\
\hline 2000 & $2.671 \mathrm{E}+11$ & $2.18 \mathrm{E}+12$ & $9.7621 \mathrm{E}+12$ & 2.23E-01 \\
\hline 2001 & $2.595 E+11$ & $2.44 \mathrm{E}+12$ & $1.002 E+13$ & $2.43 \mathrm{E}-01$ \\
\hline 2002 & $3.722 \mathrm{E}+11$ & $2.81 \mathrm{E}+12$ & $1.0383 E+13$ & $2.70 \mathrm{E}-01$ \\
\hline
\end{tabular}

Source: own calculations from data in IMF IFS Yearbook 
Figure 1 Three different regimes for debt dynamics

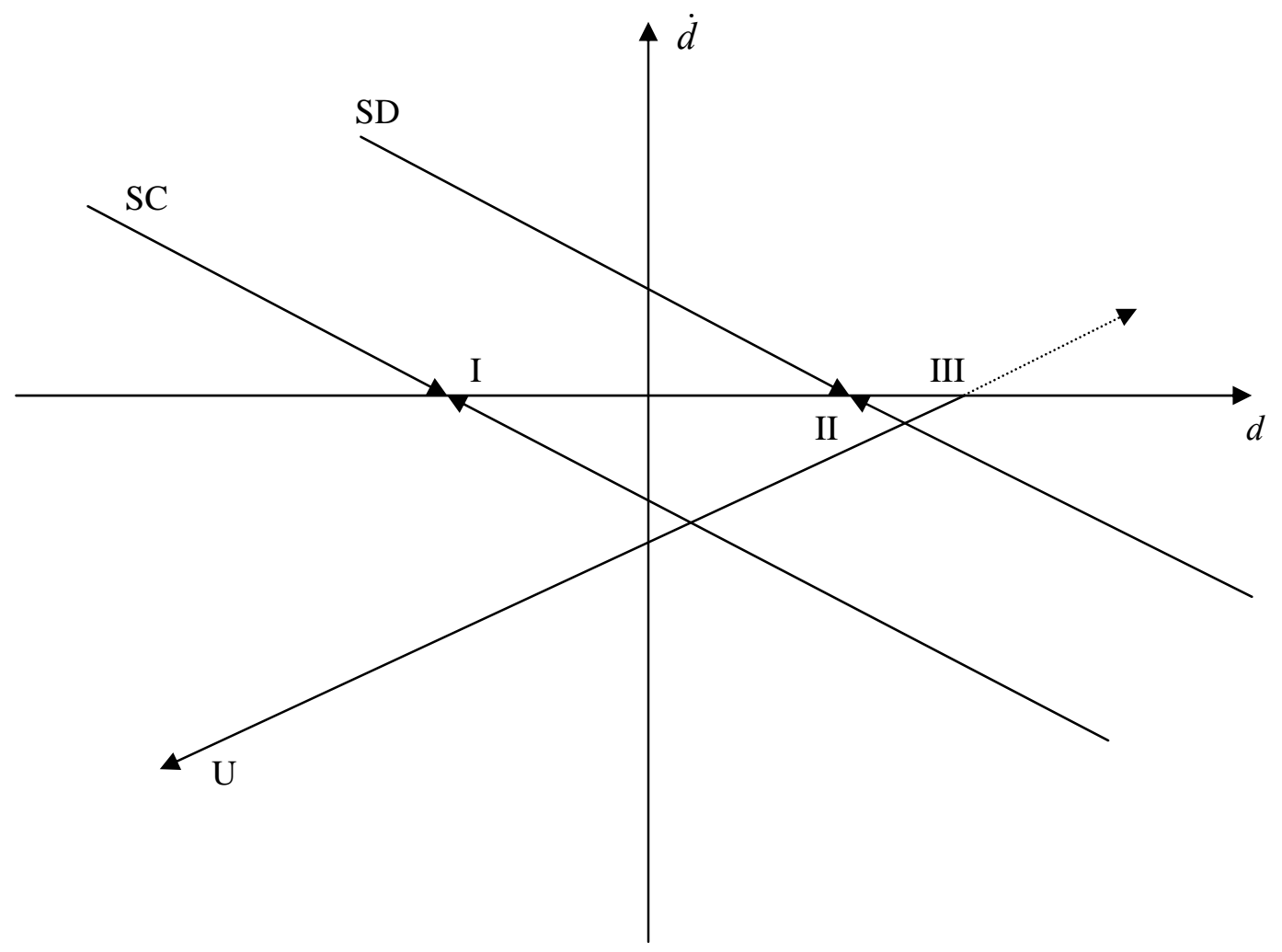




\section{Figure 2}

(a) Debt/GDP ratios

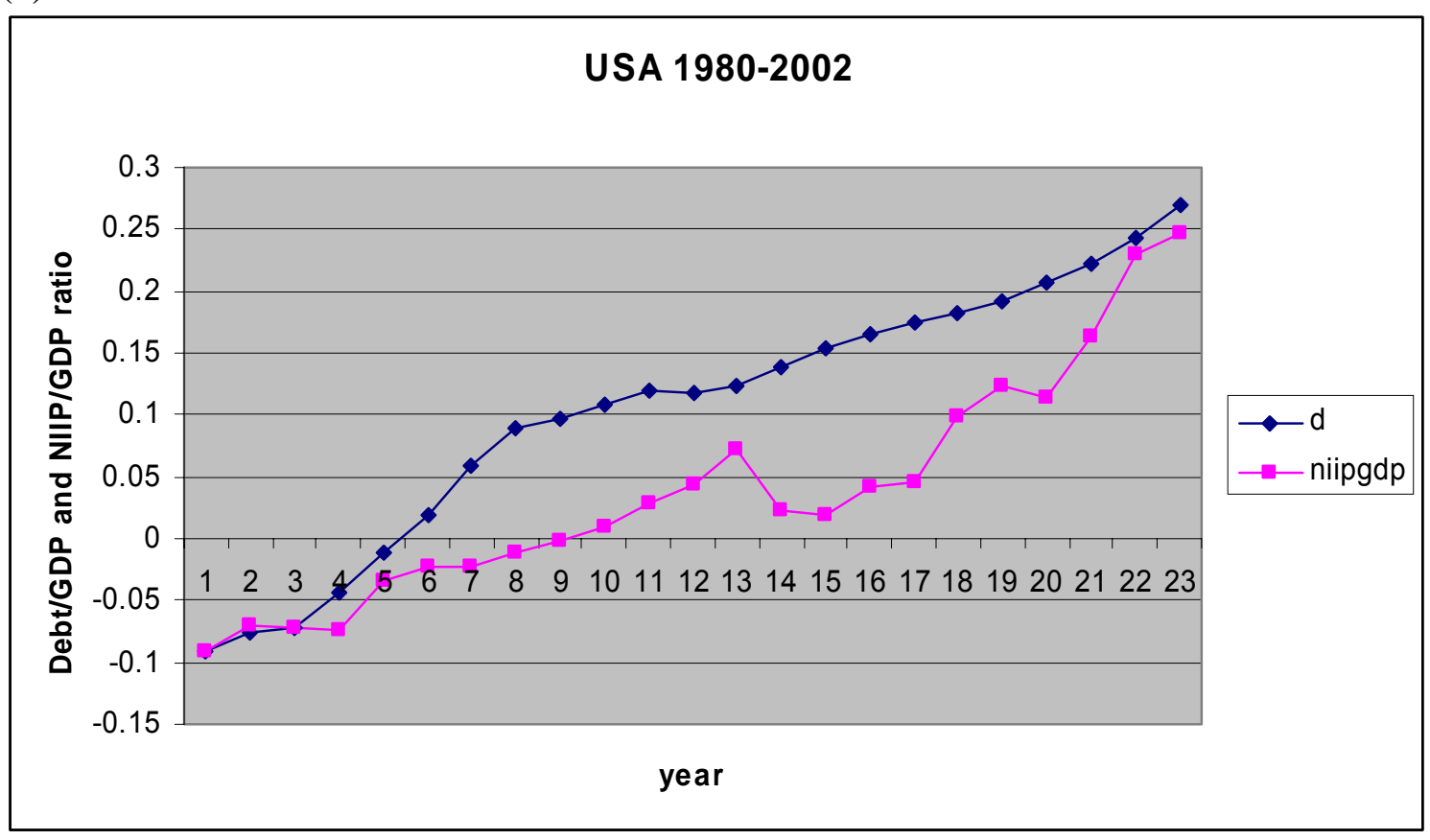

(b) Official exchange rates

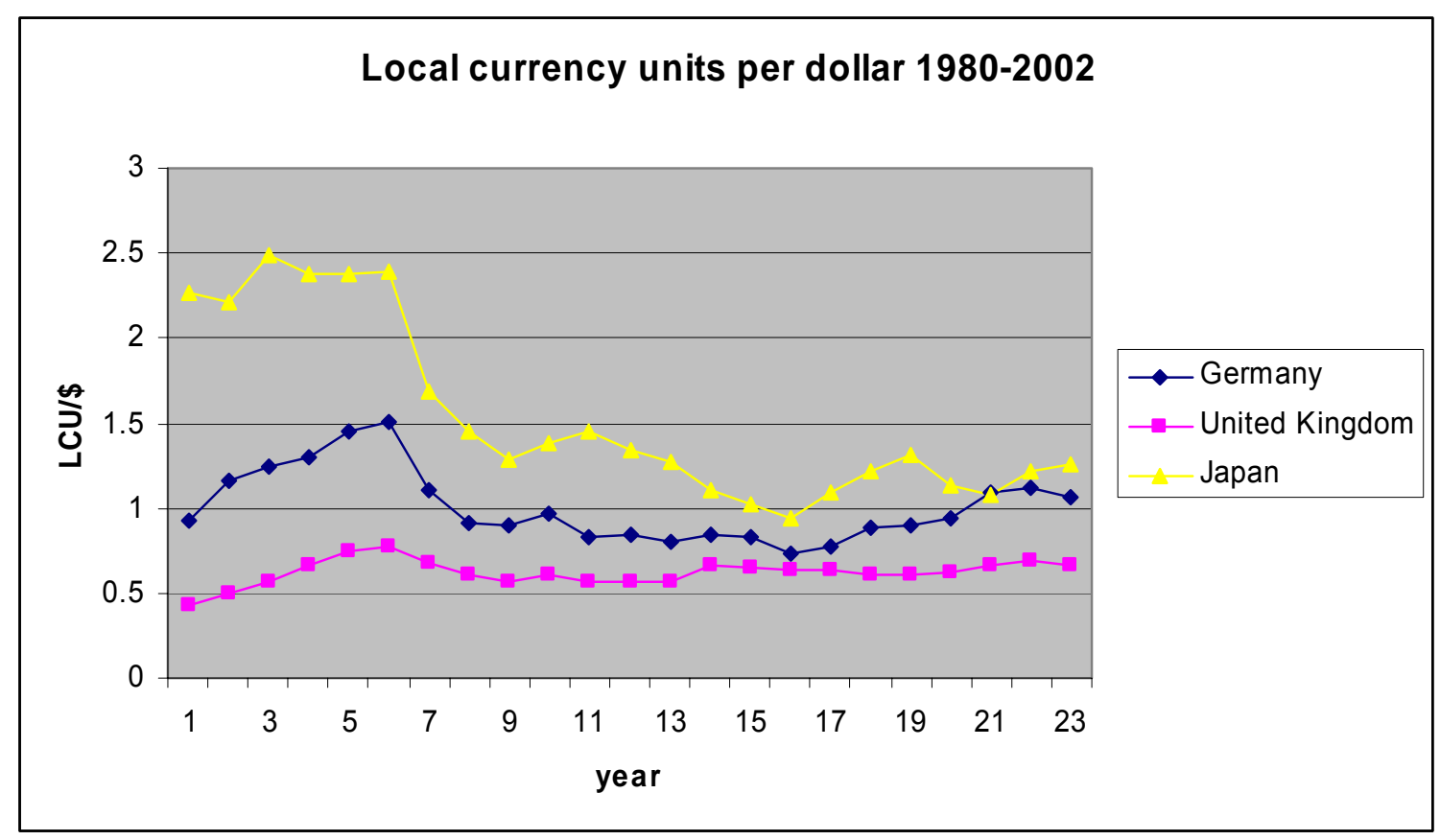




\section{Figure 3}

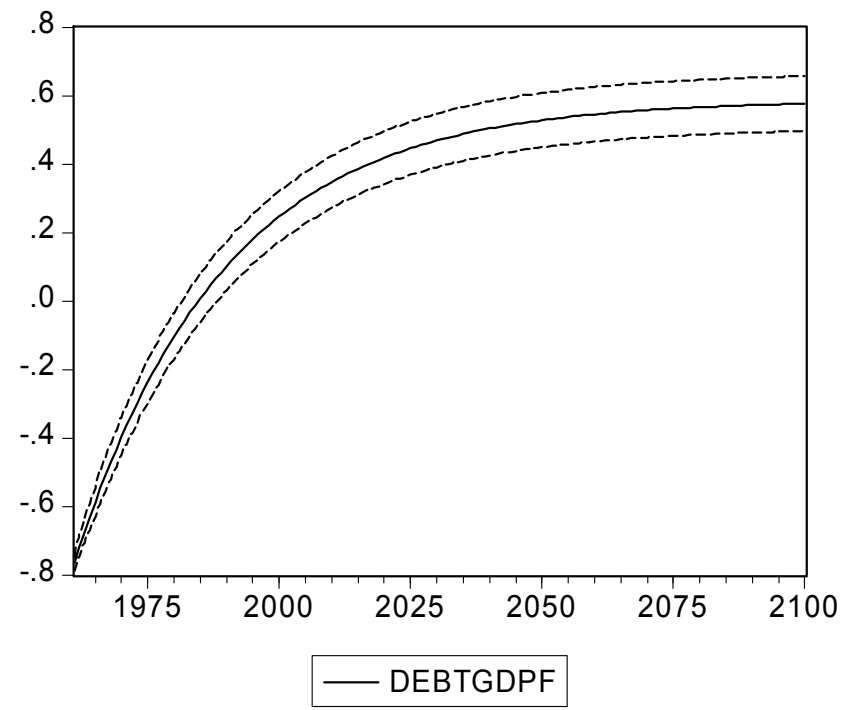

Forecast: DEBTGDPF

Actual: DEBTGDP

Forecast sample: 19602100

Adjusted sample: 19612100

Included observations: 42

Root Mean Squared Error $\quad 0.017194$

Mean Absolute Error $\quad 0.014215$

Mean Abs. Percent Error $\quad 11.44113$

Theil Inequality Coefficient $\quad 0.026062$

Bias Proportion $\quad 0.001374$

Variance Proportion $\quad 0.003496$

Covariance Proportion $\quad 0.995130$

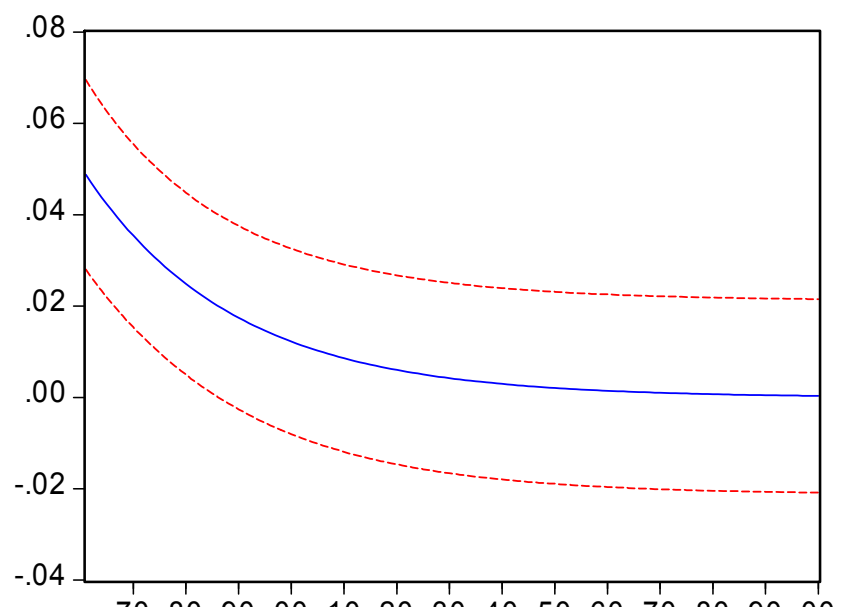

Forecast: DEBTGDPF

Actual: D(DEBTGDP)

Forecast sample: 19602100

Adjusted sample: 19612100

Included observations: 42

Root Mean Squared Error

0.009693

Mean Absolute Error

0.008140

Mean Abs. Percent Error

61.59453

Theil Inequality Coefficient

0.168028

Bias Proportion

0.000006

Variance Proportion

0.138787

Covariance Proportion

0.861207

$\begin{array}{llllllllllllll}70 & 80 & 90 & 00 & 10 & 20 & 30 & 40 & 50 & 60 & 70 & 80 & 90 & 00\end{array}$ DEBTGDPF 
Figure 4

Intercept and slope of 7-years rolling windows of the basic regression

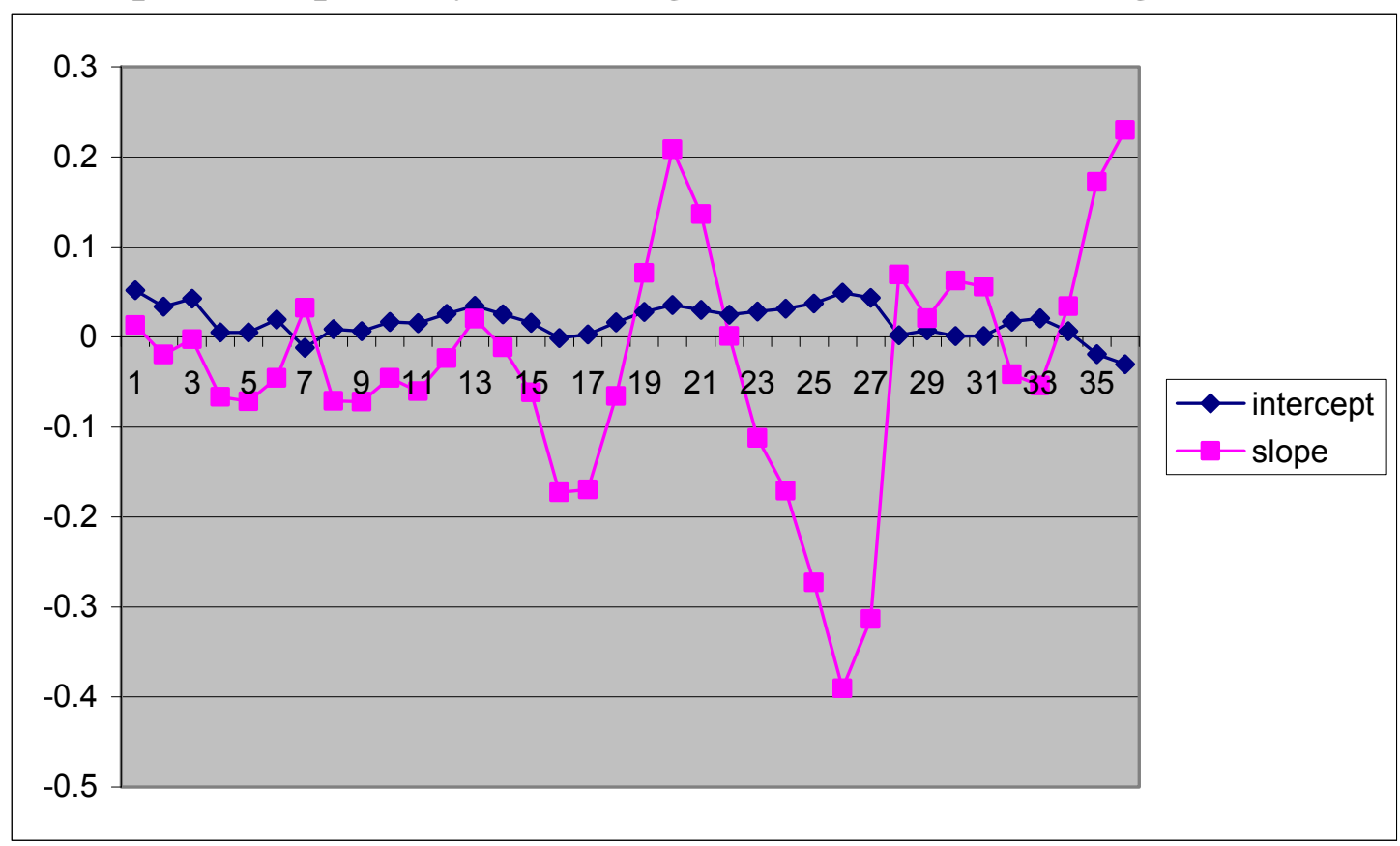


Figure 5

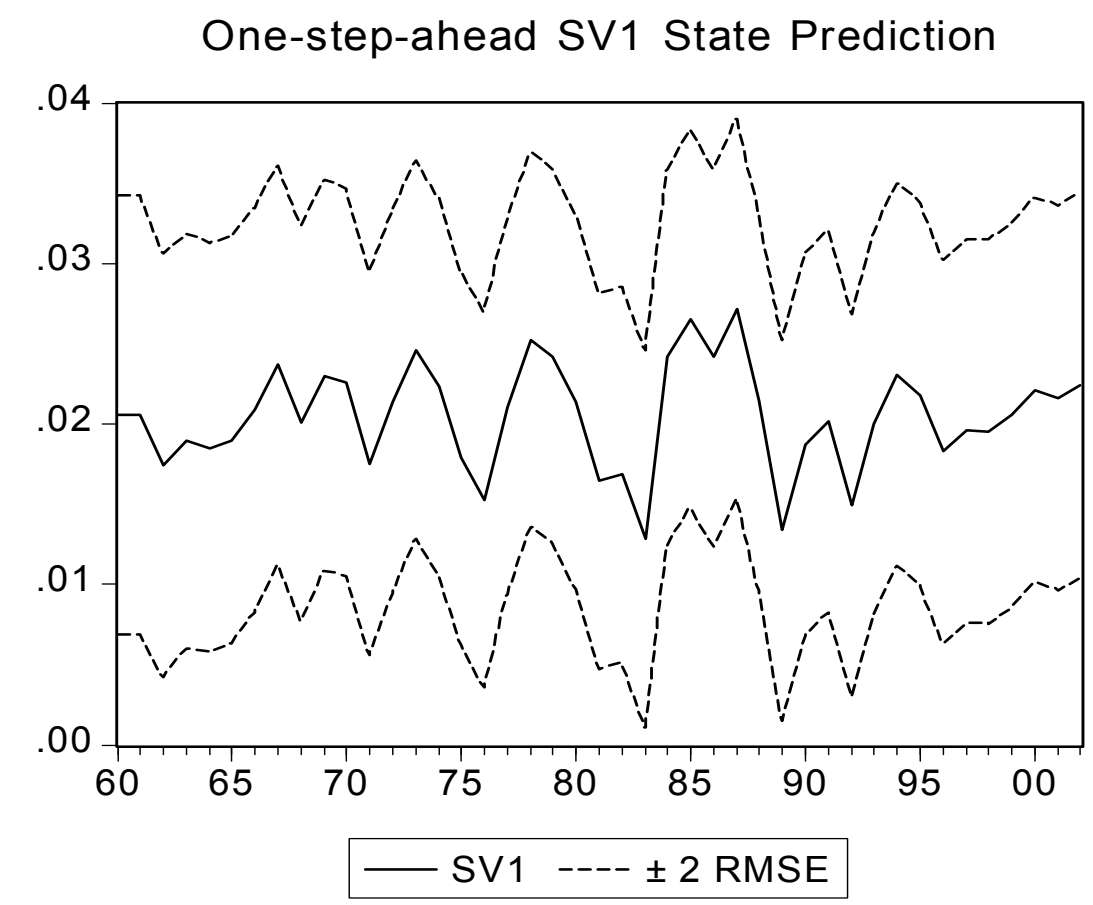

One-step-ahead SV2 State Prediction

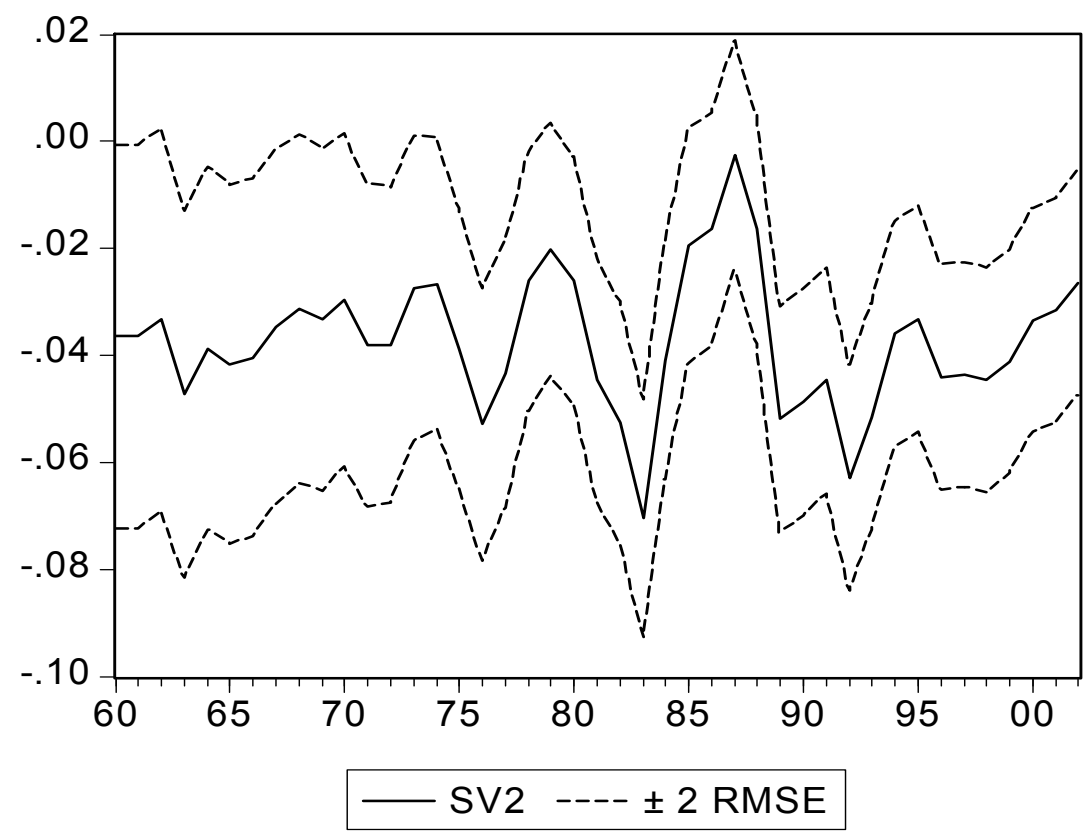


Figure 6: US Data (1960 onwards) for the growth model estimation
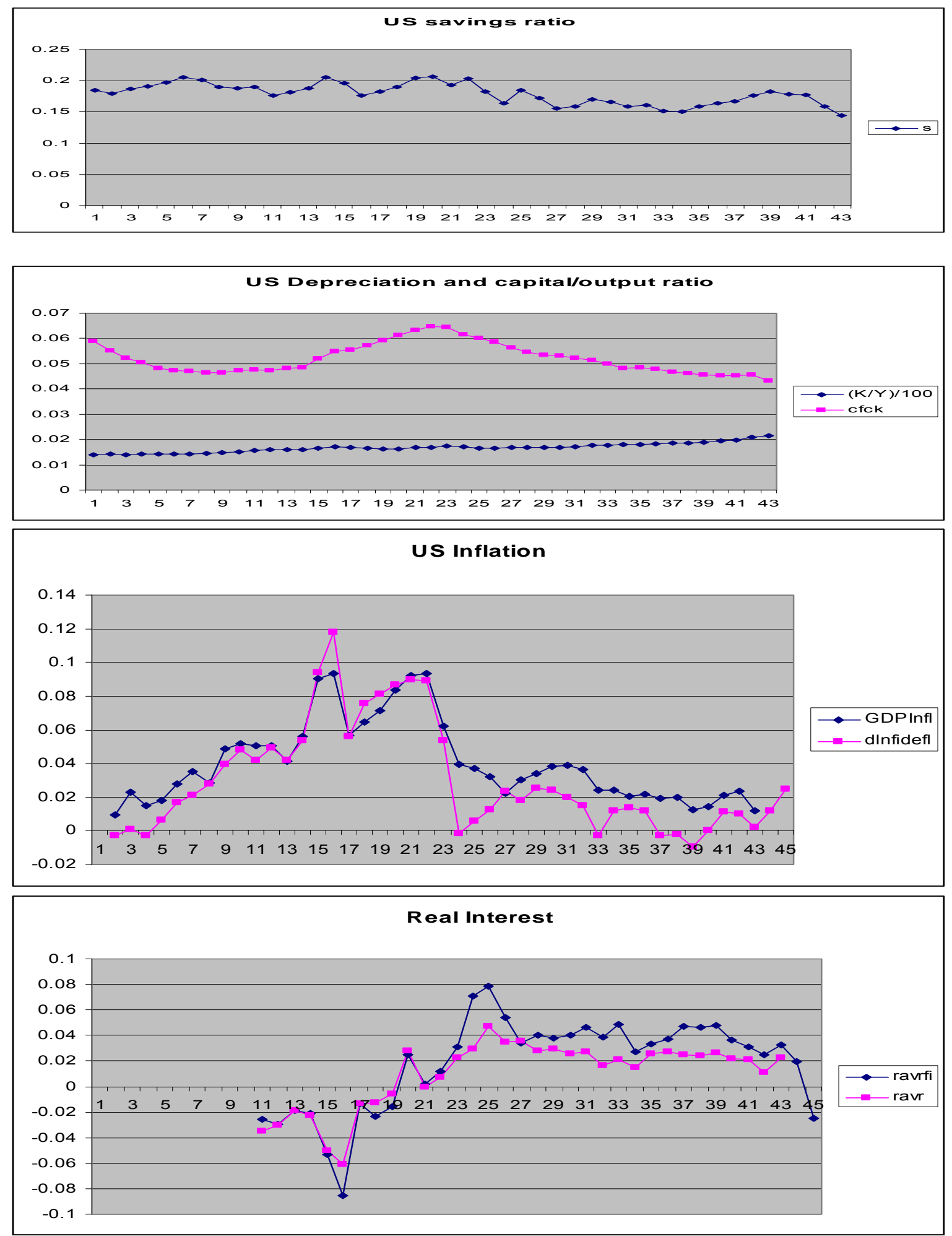

Abbreviations. dlnfidefl: growth rate of fixed investment deflator; ravrfi: interest rate deflated using fixed investment deflator. ravr: interest rate using GDP deflator. 
Table 1

Data on Financial US Capital Stocks and Income (Billions of U.S. dollars)

\begin{tabular}{|c|c|c|c|c|c|c|c|}
\hline year & Assets & Liabilities & NIIIP & $\begin{array}{l}\text { Investment } \\
\text { Credit }\end{array}$ & $\begin{array}{l}\text { income } \\
\text { Debit }\end{array}$ & $\begin{array}{l}\text { Interest } \\
\text { Credit }^{\mathrm{b}}\end{array}$ & $\begin{array}{l}\text { rate } \\
\text { Debt }^{c}\end{array}$ \\
\hline 1980 & 755.41 & 500.84 & 254.57 & 72.67 & 43.09 & 0.096 & 0.086 \\
\hline 1981 & 802.09 & 583.37 & 218.72 & 86.65 & 54.26 & 0.108 & 0.093 \\
\hline 1982 & 961.02 & 725.08 & 235.94 & 86.32 & 57.14 & 0.090 & 0.079 \\
\hline 1983 & 1129.67 & 872.28 & 257.39 & 85.26 & 54.45 & 0.075 & 0.062 \\
\hline 1984 & 1127.13 & 993.04 & 134.09 & 104.86 & 74.86 & 0.093 & 0.075 \\
\hline 1985 & 1302.71 & 1205.82 & 96.89 & 93.73 & 73.94 & 0.072 & 0.061 \\
\hline 1986 & 1594.65 & 1493.87 & 100.78 & 97.06 & 81.58 & 0.061 & 0.055 \\
\hline 1987 & 1758.71 & 1708.18 & 50.53 & 108.18 & 93.89 & 0.062 & 0.055 \\
\hline 1988 & 2008.37 & 1997.9 & 10.47 & 136.71 & 118.04 & 0.068 & 0.059 \\
\hline 1989 & 2350.24 & 2397.23 & -46.99 & 161.29 & 141.49 & 0.069 & 0.059 \\
\hline 1990 & 2294.09 & 2458.58 & -164.49 & 171.75 & 143.19 & 0.075 & 0.058 \\
\hline 1991 & 2470.63 & 2731.45 & -260.82 & 149.24 & 125.11 & 0.060 & 0.046 \\
\hline 1992 & 2466.46 & 2918.79 & -452.33 & 133.76 & 109.52 & 0.054 & 0.038 \\
\hline 1993 & 3091.4 & 3235.71 & -144.31 & 136.08 & 110.74 & 0.044 & 0.034 \\
\hline 1994 & 3315.13 & 3450.39 & -135.26 & 166.52 & 149.38 & 0.050 & 0.043 \\
\hline 1995 & 3964.56 & 4270.39 & -305.83 & 210.26 & 189.36 & 0.053 & 0.044 \\
\hline 1996 & 4650.84 & 5010.86 & -360.02 & 226.13 & 203.81 & 0.049 & 0.041 \\
\hline 1997 & 5379.13 & 6201.86 & -822.73 & 256.82 & 244.2 & 0.048 & 0.039 \\
\hline 1998 & 6174.52 & 7249.9 & -1075.4 & 261.32 & 257.55 & 0.042 & 0.036 \\
\hline 1999 & 7390.46 & 8437.12 & -1046.7 & 293.22 & 280.04 & 0.040 & 0.033 \\
\hline 2000 & 7393.64 & 8982.2 & -1588.6 & 350.45 & 329.86 & 0.047 & 0.037 \\
\hline 2001 & 6898.71 & 9206.87 & -2308.2 & 286.69 & 263.12 & 0.042 & 0.029 \\
\hline 2002 & 6613.32 & 9166.73 & -2553.4 & 266.8 & 259.63 & 0.040 & 0.028 \\
\hline 2003 & 7863.97 & 10515 & -2651 & 294.39 & 261.1 & 0.037 & 0.025 \\
\hline
\end{tabular}

Source: IMF IFSY 2004 (years 2003-1992) and older.

a Difference of columns one and two.

b Column four, inv. credit, divided by column one, assets, end of one period earlier.

c Column five, income debit, divided by column two, liabilities.

End of period data. 
Table 2

Regression on the time index (t-values in parantheses)

Independent $\rightarrow$

Dependent $\downarrow$ variable intercept t(ime) time squared Adjusted R-squared

$\log (\mathrm{I}-\mathrm{S}) \quad 20.7418 \quad 0.14043-$

0.77729

(61.64) (11.25) -

$\log (\mathrm{I}-\mathrm{S})$

$19.7596 \quad 0.25482 \quad-0.0025$

$\begin{array}{lll}(37.99) & (5.15) & -(2.38)\end{array}$

$\log G D P$

$26.90380 .07671 \quad-$

(824.49) (59.38) -

$\log \mathrm{GDP}$

$26.7118 \quad 0.10231$

$-0.0006$

0.9955

$\begin{array}{lll}(835.95) & (30.54) & -(7.88)\end{array}$ 
Table 3

Regressions for the Debt/GDP ratio, 1961-2002

(dependent variable: $\mathrm{d}(\mathrm{debt} / \mathrm{GDP})$, t-values in parantheses)

\begin{tabular}{lrrlll} 
& \multicolumn{2}{c}{ debt/ } & \multicolumn{2}{l}{ BG } & \\
Regression & intercept & GDP(-1) & adj.R ${ }^{2}$ & prob(lags). & SIC \\
LS-NW-HAC & 0.020 & -0.035 & 0.557 & $.12(1)$ & -6.29 \\
& $(9.32)$ & $-(6.31)$ & & & \\
LS-NW-HAC $^{(a)}$ & 0.020 & -0.037 & 0.694 & $.33(1)$ & -6.51 \\
& $(8.98)$ & $-(6.84)$ & & & \\
unit root regression $^{(b)}$ & 0.021 & -0.041 & 0.634 & $0.080386(1)$ & -6.29 \\
& $(3.74)$ & $-(3.33)$ & & &
\end{tabular}

a,b: Additional variables

\begin{tabular}{|c|c|c|c|c|}
\hline & Coefficient & Std. Error & t-Statistic & \\
\hline & -0.49 & 0.11 & -4.44 & 0.0 \\
\hline & 0.94 & 0.04 & 22.59 & 0.0 \\
\hline BTGDP(-1)) & 0.41 & 0.17 & 2.43 & 0.0 \\
\hline 3TGDP(-2)) & -0.18 & 0.17 & -1.01 & 0. \\
\hline & 0.05 & 0.17 & 0.32 & \\
\hline $3 \operatorname{TGDP}(-4))$ & -0.28 & 0.14 & -1.93 & \\
\hline
\end{tabular}

LS: least squares; ; NW: Newey-West; HAC: heteroscedasticity and autocorrelation correction. 
Table 4: Rolling windows for seven years

\begin{tabular}{lrrrrr} 
& & & \multicolumn{2}{c}{$p$-value } & \multicolumn{2}{l}{ adj.R- } \\
Years & intercept & slope & p-val. interc. & slope & \multicolumn{2}{l}{ squared } \\
19611967 & 0.05 & 0.01 & 0.21 & 0.82 & -0.19 \\
19621968 & 0.03 & -0.02 & 0.25 & 0.64 & -0.14 \\
19631969 & 0.04 & 0.00 & 0.12 & 0.95 & -0.20 \\
19641970 & 0.01 & -0.07 & 0.83 & 0.14 & 0.25 \\
19651971 & 0.00 & -0.07 & 0.83 & 0.14 & 0.26 \\
19661972 & 0.02 & -0.05 & 0.45 & 0.39 & -0.02 \\
19671973 & -0.01 & 0.03 & 0.15 & 0.79 & -0.18 \\
19681974 & 0.01 & -0.07 & 0.63 & 0.14 & 0.26 \\
19691975 & 0.01 & -0.07 & 0.71 & 0.16 & 0.22 \\
19701976 & 0.02 & -0.05 & 0.38 & 0.41 & -0.03 \\
19711977 & 0.02 & -0.06 & 0.35 & 0.27 & 0.09 \\
19721978 & 0.03 & -0.02 & 0.13 & 0.67 & -0.15 \\
19731979 & 0.03 & 0.02 & 0.02 & 0.65 & -0.15 \\
19741980 & 0.03 & -0.01 & 0.06 & 0.83 & -0.19 \\
19751981 & 0.02 & -0.06 & 0.15 & 0.28 & 0.07 \\
19761982 & 0.00 & -0.17 & 0.84 & 0.01 & 0.75 \\
19771983 & 0.00 & -0.17 & 0.78 & 0.05 & 0.48 \\
19781984 & 0.02 & -0.07 & 0.21 & 0.56 & -0.11 \\
19791985 & 0.03 & 0.07 & 0.03 & 0.52 & -0.10 \\
19801986 & 0.04 & 0.21 & 0.00 & 0.04 & 0.52 \\
19811987 & 0.03 & 0.14 & 0.00 & 0.13 & 0.28 \\
19821988 & 0.02 & 0.00 & 0.01 & 0.99 & -0.20 \\
19831989 & 0.03 & -0.11 & 0.00 & 0.13 & 0.28 \\
19841990 & 0.03 & -0.17 & 0.00 & 0.04 & 0.54 \\
19851991 & 0.04 & -0.27 & 0.00 & 0.01 & 0.71 \\
19861992 & 0.05 & -0.39 & 0.00 & 0.00 & 0.89 \\
19871993 & 0.04 & -0.31 & 0.03 & 0.06 & 0.43 \\
19881994 & 0.00 & 0.07 & 0.94 & 0.69 & -0.16 \\
19891995 & 0.01 & 0.02 & 0.72 & 0.90 & -0.20 \\
19901996 & 0.00 & 0.06 & 0.96 & 0.66 & -0.15 \\
19911997 & 0.00 & 0.06 & 0.96 & 0.66 & -0.15 \\
19921998 & 0.02 & -0.04 & 0.12 & 0.52 & -0.09 \\
19931999 & 0.02 & -0.05 & 0.08 & 0.39 & -0.02 \\
19942000 & 0.01 & 0.03 & 0.62 & 0.63 & -0.14 \\
19952001 & -0.02 & 0.17 & 0.02 & 0.00 & 0.83 \\
19962002 & -0.03 & 0.23 & 0.00 & 0.00 & 0.92
\end{tabular}




\begin{tabular}{|c|c|c|c|}
\hline \multirow[t]{3}{*}{ Table 5} & \multicolumn{3}{|c|}{$\begin{array}{l}\text { Maximum likelihood estimation results } \\
\text { of the state-space model ( } p \text {-values in parantheses) }\end{array}$} \\
\hline & Regr.1 & Regr.2 & Regr.3 \\
\hline & Coeff.(p-val.) & Coeff.(p-val.) & Coeff.(p-val.) \\
\hline \multirow[t]{2}{*}{$C(2)$} & 0.021 & 0.021 & 0.021 \\
\hline & $(0.00)$ & $(0.00)$ & $(0.00)$ \\
\hline \multirow[t]{2}{*}{$C(3)$} & -0.036 & -0.035 & -0.036 \\
\hline & $(0.00)$ & $(0.00)$ & $(0.00)$ \\
\hline \multirow[t]{2}{*}{$C(6)$} & -10.64 & -10.39 & -10.60 \\
\hline & $(0.00)$ & $(0.00)$ & $(0.00)$ \\
\hline \multirow[t]{2}{*}{$\mathrm{C}(8)$} & 0.97 & 0.52 & 0.82 \\
\hline & $(0.08)$ & $(0.01)$ & $(0.00)$ \\
\hline \multirow[t]{2}{*}{$\mathrm{C}(9)$} & -0.21 & - & -0.16 \\
\hline & $(0.37)$ & & $(0.19)$ \\
\hline \multirow[t]{2}{*}{$C(10)$} & 3.11 & 2.11 & 2.52 \\
\hline & $(0.10)$ & $(0.10)$ & $(0.08)$ \\
\hline \multirow[t]{2}{*}{$C(11)$} & $\begin{array}{l}-0.41 \\
(0.59)\end{array}$ & - & - \\
\hline & Final State & Final Stat & Final State \\
\hline \multirow[t]{2}{*}{ SV1 } & 0.021 & 0.025 & 0.024 \\
\hline & $(0.00)$ & $(0.00)$ & $(0.00)$ \\
\hline \multirow[t]{2}{*}{ SV2 } & -0.036 & -0.020 & -0.017 \\
\hline & $(0.05)$ & $(0.04)$ & $(0.10)$ \\
\hline Log likelihood & 141.0 & 139.7 & 140.939 \\
\hline Parameters & 7 & 5 & 6 \\
\hline Diffuse priors & 0 & 0 & 0 \\
\hline $\mathrm{AIC}$ & -6.38 & -6.42 & -6.42 \\
\hline SIC & -6.09 & -6.21 & -6.21 \\
\hline HQC & -6.28 & -6.34 & -6.34 \\
\hline Val.Obs. & 42 & 42 & 42 \\
\hline
\end{tabular}

AIC: Akaike info criterion; SIC: Schwarz criterion; HQC: Hannan-Quinn criter. 
Table 6: GMM-HAC Regression results for the non-linear growth model

\begin{tabular}{|c|c|c|c|}
\hline & $\begin{array}{l}\text { Coeff. } \\
\text { (t-val.) }\end{array}$ & $\begin{array}{l}\text { Coeff. } \\
\text { (t-val.) }\end{array}$ & $\begin{array}{l}\text { Coeff. } \\
\text { (t-val.) }\end{array}$ \\
\hline$C(1)$ & $\begin{array}{l}0.08 \\
(1.69)\end{array}$ & $\begin{array}{l}0.08 \\
(4.80)\end{array}$ & $\begin{array}{l}0.00 \\
-(0.09)\end{array}$ \\
\hline $\mathrm{C}(2)$ & $\begin{array}{l}0.05 \\
(1.78)\end{array}$ & $\begin{array}{l}0.06 \\
(5.01)\end{array}$ & $\begin{array}{l}0.05 \\
(5.39)\end{array}$ \\
\hline$c(3)$ & $=c(2)$ & $=c(2)$ & $\begin{array}{l}0.10 \\
(7.10)\end{array}$ \\
\hline $\begin{array}{l}0 \\
(3\end{array}$ & $\begin{array}{l}0.34 \\
(3.88)\end{array}$ & $\begin{array}{l}0.38 \\
(11.03)\end{array}$ & $\begin{array}{l}0.11 \\
(11.94)\end{array}$ \\
\hline$\rho$ & $\begin{array}{l}-1.85 \\
-(3.82)\end{array}$ & $\begin{array}{l}-2.06 \\
-(12.86)\end{array}$ & $\begin{array}{l}-5.42 \\
-(19.76)\end{array}$ \\
\hline A-level 1983 & $\begin{array}{l}321311.70 \\
(29.71)\end{array}$ & $\begin{array}{l}318821.70 \\
(60.43)\end{array}$ & $\begin{array}{l}351159.80 \\
(153.26)\end{array}$ \\
\hline A growth rate & $\begin{array}{l}0.0152 \\
(37.92)\end{array}$ & $\begin{array}{l}0.0150 \\
(83.50)\end{array}$ & $\begin{array}{l}0.0165 \\
(73.31)\end{array}$ \\
\hline lag. Depend. & 0/0/0 & $0 / 0 / 0$ & $2 / 3 / 0$ \\
\hline No.instr (a) & 0/0/0 & $6 / 0 / 3$ & $4 / 2 / 4$ \\
\hline J-statistic & 0.33 & 0.38 & 0.36 \\
\hline Adjusted R-squared0 & 0.00 & 0.00 & 0.61 \\
\hline & 0.70 & 0.71 & 0.96 \\
\hline & 1.00 & 1.00 & 0.99 \\
\hline Durbin-Watson stat 0 & 0.59 & 0.60 & 1.84 \\
\hline & 0.66 & 0.60 & 1.27 \\
\hline & 0.59 & 0.58 & 0.41 \\
\hline Obs. & $19 / 19 / 20$ & $19 / 19 / 20$ & $19 / 19 / 20$ \\
\hline
\end{tabular}

(a) Instruments in addition to the regressors: number of lagged endogenous variables. 


\begin{tabular}{|c|c|c|c|c|}
\hline \multicolumn{5}{|c|}{ Appendix C (NOT FOR PUBLICATION) } \\
\hline \multicolumn{5}{|c|}{ Sspace: UNTITLED } \\
\hline \multicolumn{5}{|c|}{ Method: Maximum likelihood (Marquardt) } \\
\hline \multicolumn{5}{|c|}{ Date: $12 / 09 / 04$ Time: $14: 12$} \\
\hline \multicolumn{5}{|c|}{ Included observations: 141} \\
\hline \multicolumn{5}{|c|}{ Valid observations: 42} \\
\hline \multicolumn{5}{|c|}{ Estimation settings: tol $=0.00010$, derivs $=$ accurate numeric } \\
\hline \multicolumn{5}{|c|}{$\begin{array}{l}\text { Initial Values: } C(2)=0.02101, C(3)=-0.03671, C(6)=-9.80720, \\
C(8)=0.60117 C(9)=-0.13181 \quad C(10)=237148, C(11)=-0.26260\end{array}$} \\
\hline \multicolumn{5}{|c|}{ Convergence achieved after 31 iterations } \\
\hline & Coefficient & Std. Error & z-Statistic & Prob. \\
\hline$C(2)$ & 0.020772 & 0.002404 & 8.639336 & 0.0000 \\
\hline$C(3)$ & -0.036316 & 0.005967 & -6.086191 & 0.0000 \\
\hline C(6) & -10.64260 & 0.398508 & -26.70615 & 0.0000 \\
\hline $\mathrm{C}(8)$ & 0.971941 & 0.559465 & 1.737269 & 0.0823 \\
\hline$C(9)$ & -0.206401 & 0.227941 & -0.905503 & 0.3652 \\
\hline$C(10)$ & 3.111039 & 1.892069 & 1.644253 & 0.1001 \\
\hline \multirow{2}{*}{$\mathrm{C}(11)$} & -0.407724 & 0.747180 & -0.545685 & 0.5853 \\
\hline & Final State & Root MSE & z-Statistic & Prob. \\
\hline SV1 & 0.020772 & 0.007103 & 2.924427 & 0.0035 \\
\hline SV2 & -0.036316 & 0.018532 & -1.959583 & 0.0500 \\
\hline Log likelihood & 141.0412 & Akaike & criterion & -6.382914 \\
\hline Parameters & 7 & Schwar & riterion & -6.093303 \\
\hline Diffuse priors & 0 & Hannan & uinn criter. & -6.276760 \\
\hline \multicolumn{5}{|l|}{ Wald Test: } \\
\hline \multicolumn{5}{|l|}{ SSpace: SS01 } \\
\hline Null Hypothesis: & $\begin{array}{l}C(9)=0 \\
C(11)=0\end{array}$ & & & \\
\hline Chi-square & 0.920880 & Probability & 0.6310 & \\
\hline
\end{tabular}

$c(6)$ indicates that the variance is $\exp [c(5)]=\exp \{-10.64260\}=-2.38769 \mathrm{E}-05$, which is very close to zero. $c(8)=.97$ and $c(9)=-.2$ means that a positive (negative) deviation of the intercept sv1 from its mean $\mathrm{c}(2)$ in period $\mathrm{t}$ enhances or diminishes sv1 by .97 times that deviation and a positive (negative) deviation of the of the slope coefficient sv2 from its means reduces (enhances) the intercept by -.2 that deviation. A similar interpretation holds for $c(10)$ and $c(11)$ in regard to the equation for the slope coefficient. Note that here the coefficients are negative. The trace of the corresponding differential equation system is, $c(8)-1+c(11)-1=.97-1+(-0.41-1)=-1.44$, and the determinant $=(.97-1) \times(-0.41-1)-[3.11 \times-0.2]=.66$. With a negative trace and a positive determinant the system is stable. As four times the determinant is larger than the squared trace (see Chiang 1984, p.642/643) we have a stable focus. The stationary loci of the above system then are (writing a for sv1 and $b$ for sv2, both diminished by there means $\mathrm{c}(2), \mathrm{c}(3)$ respectively):

$[c(8)-1] a+c(9) b=0$, implies $a=b x c(9) /[1-c(8)]=b(-.2 / .03)$

$c(10) a+[c(11)-1] b=0$, implies $a=[1-c(11)] b / c(10)=b(-.59 / 3.11)$.

The eigenvalues of the differential equation system are -.72+.38197i,-.72-.38197i.

When c(9) and c(11) are dropped because of the F-test result given above we get:

Sspace: SSO2

Method: Maximum likelihood (Marquardt)

Date: $12 / 14 / 04$ Time: $16: 25$

Included observations: 43

Valid observas: 42

Estimation settings: tol $=0.00010$, derivs $=$ accurate numeric

Initial Values: $C(2)=0.02077, C(3)=-0.03631, C(6)=-10.6426$, 


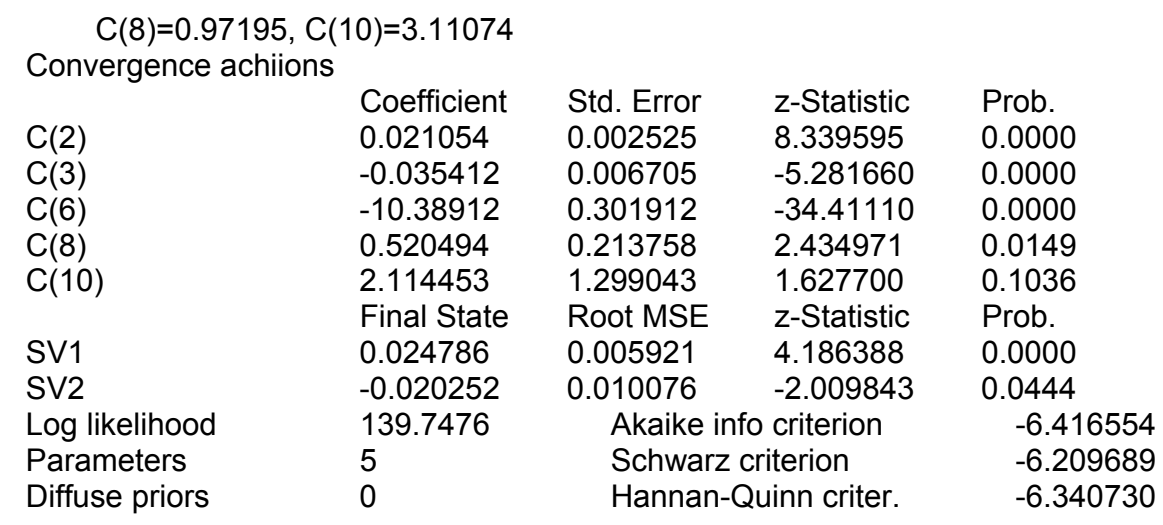

The trace of the corresponding differential equation system is, $c(8)-1+c(11)-1=.52-1+(0-1)=-1.48$, and the determinant $=(.52-1) \times(0-1)-[2.11 \times 0]=.48$. With a negative trace and a positive determinant the system is stable. The first equation then is $s v 1=c(2)+.52(\operatorname{sv} 1(-1)-c(2))$. This a stable difference equation. The second equation is sv2 $=c(3)+2.11(\operatorname{sv} 1(-1)-c(2))$. As sv1 approaches $c(2)$, sv2 goes to $c(3)$.

The stationary loci of the differential equation system then are (writing $a$ for sv1 and $b$ for sv2, both diminished by there means $\mathrm{c}(2), \mathrm{c}(3)$ respectively):

$d a / d t=[c(8)-1] a+c(9) b=0$, implies $a=b \times c(9) /[1-c(8)]=0 \times b$

$d b / d t=c(10) a+[c(11)-1] b=0$, implies $a=[1-c(11)] b / c(10)=1 b / 2.11$.

If $a$ is on vertical and $b$ on the horizontal axis, then the first locus is just the horizontal axis. The second is positively sloped. The eigenvalues of the differential equation system are -1.0,-.47951. We have a stable node in a-b-space.

The implied absence of cyclical movements is unable to explain the ups and downs in the rolling windows regressions. Therefore it may be better not to drop c(9). If only c(11) is dropped from the first regression the result is as follows:

\begin{tabular}{|c|c|c|c|c|}
\hline \multicolumn{5}{|l|}{ Sspace: SS02 } \\
\hline \multicolumn{5}{|c|}{ Date: $12 / 16 / 04$ Time: $13: 08$} \\
\hline \multicolumn{5}{|c|}{ Included observations: 43} \\
\hline \multicolumn{5}{|c|}{ Valid observns: 42} \\
\hline \multicolumn{5}{|c|}{ Estimation settings: tol $=0.00010$, derivs $=$ accurate numeric } \\
\hline $\begin{array}{l}\text { Initial Values: } \\
\mathrm{C}(8)=0.52 \\
\text { Convergence }\end{array}$ & \multicolumn{2}{|c|}{$C(8)=0.52050, C(9)=-0.20642, C(10)=2.11428$} & & \\
\hline & Coefficient & Std. Error & z-Statistic & Prob. \\
\hline$C(2)$ & 0.020596 & 0.002161 & 9.529071 & 0.0000 \\
\hline $\mathrm{C}(3)$ & -0.036434 & 0.005920 & -6.154081 & 0.0000 \\
\hline $\mathrm{C}(6)$ & -10.59786 & 0.335409 & -31.59680 & 0.0000 \\
\hline $\mathrm{C}(8)$ & 0.824803 & 0.231715 & 3.559562 & 0.0004 \\
\hline $\mathrm{C}(9)$ & -0.162270 & 0.122581 & -1.323779 & 0.1856 \\
\hline \multirow[t]{2}{*}{$C(10)$} & 2.517992 & 1.458854 & 1.726006 & 0.0843 \\
\hline & Final State & Root MSE & z-Statistic & Prob. \\
\hline SV1 & 0.024121 & 0.006025 & 4.003712 & 0.0001 \\
\hline SV2 & -0.017109 & 0.010496 & -1.629948 & 0.1031 \\
\hline Log likelihood & 140.9390 & Akaike & criterion & -6.425667 \\
\hline Parameters & 6 & Schwar & riterion & -6.177429 \\
\hline Diffuse priors & 0 & Hannar & uinn criter. & -6.334678 \\
\hline
\end{tabular}

The variance is again very close to zero. The trace of the corresponding differential equation system is, $c(8)-1+c(11)-1=.825-1+(0-1)=-1.175$, and the determinant $=(.825-1) \times(0-1)-[2.52 \times-0.16]=$ .578 With a negative trace and a positive determinant the system is stable. As four times the determinant is 
larger than the squared trace (see Chiang 1984, p.642/643) we have a stable focus. The stationary loci of the above system then are (writing $a$ for sv1 and $b$ for sv2, both diminished by there means $c(2), c(3)$ respectively):

$[c(8)-1] a+c(9) b=0$, implies $a=b x c(9) /[1-c(8)]=b(-.16 / .175)$

$c(10) a+[c(11)-1] b=0$, implies $a=[1-c(11)] b / c(10)=b(1 / 2.52)$.

The eigenvalues of the differential equation system are -.5876+.48838i, -.5876-. 48838i.

\section{Appendix D (NOT FOR PUBLICATION)}

\section{Vector Error Correction Estimates}

Date: 04/20/05 Time: 16:30

Sample (adjusted): 19832002

Included observations: 20 after adjustments

Standard eors in ( ) \& t-statistics in [ ]

\begin{tabular}{|c|c|c|}
\hline Cointegrating Eq: & CointEq1 & \\
\hline RAVR(-1) & 1.000000 & \\
\hline DEBTGDP(-1) & $\begin{array}{r}0.369567 \\
(0.11008) \\
{[3.35740]}\end{array}$ & \\
\hline @TREND(60) & $\begin{array}{r}-0.004121 \\
(0.00145) \\
{[-2.84379]}\end{array}$ & \\
\hline C & 0.065933 & \\
\hline Error Correction: & $\mathrm{D}(\mathrm{RAVR})$ & $\mathrm{D}$ (DEBTGDP) \\
\hline CointEq1 & $\begin{array}{r}-0.484849 \\
(0.15885) \\
{[-3.05227]}\end{array}$ & $\begin{array}{r}-0.596727 \\
(0.19627) \\
{[-3.04038]}\end{array}$ \\
\hline $\mathrm{D}(\mathrm{RAVR}(-1))$ & $\begin{array}{r}-0.401761 \\
(0.16748) \\
{[-2.39881]}\end{array}$ & $\begin{array}{r}-0.026816 \\
(0.20694) \\
{[-0.12959]}\end{array}$ \\
\hline $\mathrm{D}(\mathrm{RAVR}(-2))$ & $\begin{array}{r}0.116134 \\
(0.19836) \\
{[0.58548]}\end{array}$ & $\begin{array}{r}0.083118 \\
(0.24508) \\
{[0.33914]}\end{array}$ \\
\hline $\mathrm{D}(\mathrm{DEBTGDP}(-1))$ & $\begin{array}{r}0.118037 \\
(0.14545) \\
{[0.81155]}\end{array}$ & $\begin{array}{r}0.669306 \\
(0.17971) \\
{[3.72440]}\end{array}$ \\
\hline
\end{tabular}




\begin{tabular}{lrr}
\multicolumn{1}{c}{ D(DEBTGDP(-2)) } & -0.085928 & 0.110832 \\
& $(0.15202)$ & $(0.18783)$ \\
& {$[-0.56524]$} & {$[0.59006]$} \\
& & \\
& -0.000554 & 0.004586 \\
& $(0.00265)$ & $(0.00327)$ \\
& {$[-0.20949]$} & {$[1.40274]$} \\
\hline \hline R-squared & 0.620762 & 0.702316 \\
Adj. R-squared & 0.485320 & 0.596001 \\
Sum sq. resids & 0.000436 & 0.000666 \\
S.E. equation & 0.005581 & 0.006896 \\
F-statistic & 4.583235 & 6.605957 \\
Log likelihood & 78.95400 & 74.72348 \\
Akaike AIC & -7.295400 & -6.872348 \\
Schwarz SC & -6.996680 & -6.573629 \\
Mean dependent & $1.48 \mathrm{E}-05$ & 0.017065 \\
S.D. dependent & 0.007780 & 0.010850 \\
\hline \hline Determinant resid covariance (dof adj.) & $1.26 \mathrm{E}-09$ \\
Determinant resid covariance & $6.19 \mathrm{E}-10$ \\
Log likelihood & 155.2753 \\
Akaike information criterion & & -14.02753 \\
Schwarz criterion & -13.28073 \\
\hline \hline
\end{tabular}

Vector Error Correction Estimates

Date: 04/20/05 Time: 16:39

Sample (adjusted): 19832002

Included observations: 20 after adjustments

Standard errors in ( ) \& t-statistics in [ ]

\begin{tabular}{cr}
\hline \hline Cointegrating Eq: & CointEq1 \\
\hline \hline RAVR(-1) & 1.000000 \\
& \\
DEBTGDP(-1) & 0.060032 \\
& $(0.05982)$ \\
& {$[1.00351]$} \\
& -0.000105 \\
@TREND(60) & $(0.00088)$ \\
& {$[-0.11882]$} \\
& -0.029215 \\
\hline
\end{tabular}




\begin{tabular}{lrr}
\multicolumn{1}{c}{ Error Correction: } & D(RAVR) & D(DEBTGDP) \\
\hline \hline \multicolumn{1}{c}{ CointEq1 } & -0.874358 & 0.024760 \\
& $(0.19690)$ & $(0.39745)$ \\
& {$[-4.44058]$} & {$[0.06230]$} \\
& & \\
& $1.48 \mathrm{E}-05$ & 0.017065 \\
& $(0.00123)$ & $(0.00249)$ \\
& {$[0.01198]$} & {$[6.84706]$} \\
\hline \hline R-squared & 0.522784 & 0.000216 \\
Adj. R-squared & 0.496272 & -0.055328 \\
Sum sq. resids & 0.000549 & 0.002236 \\
S.E. equation & 0.005522 & 0.011146 \\
F-statistic & 19.71878 & 0.003881 \\
Log likelihood & 76.65593 & 62.60840 \\
Akaike AIC & -7.465593 & -6.060840 \\
Schwarz SC & -7.366020 & -5.961267 \\
Mean dependent & $1.48 \mathrm{E}-05$ & 0.017065 \\
S.D. dependent & 0.007780 & 0.010850 \\
\hline \hline Determinant resid covariance (dof adj.) & $3.37 \mathrm{E}-09$ \\
Determinant resid covariance & $2.73 \mathrm{E}-09$ \\
Log likelihood & & 140.4206 \\
Akaike information criterion & & -13.34206 \\
Schwarz criterion & & -12.99355 \\
\hline \hline
\end{tabular}

Dropping the time trend does not change the sign and order of magnitude of the debt term but makes it more significant.

\section{Appendix E (NOT FOR PUBLICATION)}

Abbreviations:

cfck: consumption of fixed capital as a share of the capital stock

debtgdp: debt/ GDP ratio

empl: Employment in thousand worker

GDPR: real GDP

KR2: capital stock

Inrplusd: natural log of the sum of real interest rate and depreciation rate

log: natural logarithm

RAVR: real interest rate

$\mathrm{s}$ : savings ratio

GMM-HAC Estimate of the model without instruments and autocorrelation correction

System: SYS13

Estimation Method: Generalized Method of Moments

Date: 04/13/05 Time: 17:35

Sample: 19832002 
Included observations: 20

Total system (unbalanced) observations 58

Estimation settings: tol $=0.00010$, derivs $=$ analytic

Initial Values: $\mathrm{C}(1)=0.04220, \mathrm{C}(2)=0.07846, \mathrm{C}(4)=0.42502, \mathrm{C}(5)=$

$-2.29362, C(11)=310439 ., C(12)=0.01525$

Kernel: Bartlett, Bandwidth: Fixed (2), No prewhitening

Iterate coefficients after one-step weighting matrix

Convergence achieved after: 1 weight matrix, 8 total coef iterations

\begin{tabular}{ccccc}
\hline \hline & Coefficient & Std. Error & t-Statistic & Prob. \\
\hline \hline $\mathrm{C}(1)$ & 0.082520 & 0.048851 & 1.689214 & 0.0972 \\
$\mathrm{C}(2)$ & 0.053447 & 0.030009 & 1.781051 & 0.0807 \\
$\mathrm{C}(4)$ & 0.343265 & 0.088386 & 3.883725 & 0.0003 \\
$\mathrm{C}(5)$ & -1.853490 & 0.485363 & -3.818773 & 0.0004 \\
$\mathrm{C}(11)$ & 321311.7 & 10815.83 & 29.70755 & 0.0000 \\
$\mathrm{C}(12)$ & 0.015154 & 0.000400 & 37.92057 & 0.0000 \\
\hline \hline \multirow{2}{*}{$\begin{array}{l}\text { Determinant residual covariance } \\
\text { J-statistic }\end{array}$} & $7.12 \mathrm{E}-12$ & & \\
\hline \hline
\end{tabular}

Equation: DDEBTGDP + $S^{*}(1-$ RAVR*DEBTGDP(-1)-CFCK KR2(-1)

$/ G D P R)=C(1)+C(2)^{*} K R 2(-1) / G D P R-C(2)^{*}$ DEBTGDP $(-1)$

Instruments: C KR2(-1)/GDPR DEBTGDP(-1)

Observations: 19

\begin{tabular}{llll}
\hline R-squared & 0.057176 & Mean dependent var & 0.168757 \\
Adjusted R-squared & 0.001716 & S.D. dependent var & 0.014246 \\
S.E. of regression & 0.014234 & Sum squared resid & 0.003444 \\
Durbin-Watson stat & 0.592442 & & \\
\hline \hline
\end{tabular}

Equation: LOG(KR2(-1)/GDPR(+0)) $=(\operatorname{LNRPLUSD}-\operatorname{LOG}(\mathrm{C}(4))) /(-1$

$+C(5))$

Instruments: C LNRPLUSD

Observations: 19

\begin{tabular}{llll}
\hline R-squared & 0.720735 & Mean dependent var & 0.541292 \\
Adjusted R-squared & 0.704308 & S.D. dependent var & 0.057766 \\
S.E. of regression & 0.031412 & Sum squared resid & 0.016774 \\
Durbin-Watson stat & 0.663484 & &
\end{tabular}

Equation: $\operatorname{LOG}(\mathrm{GDPR})=(1 / \mathrm{C}(5))^{*} \operatorname{LOG}\left(\mathrm{C}(4)^{*}\left(\mathrm{KR} 2(-1)^{\wedge} \mathrm{C}(5)\right)+(1-\mathrm{C}(4))\right.$

$\left.{ }^{*}\left(\mathrm{C}(11)^{*}\left(\operatorname{EXP}\left(\mathrm{C}(12)^{*} \mathrm{~T}\right)\right)^{*} \mathrm{EMPL}\right)^{\wedge} \mathrm{C}(5)\right)$

Instruments: C KR2(-1) T EMPL

Observations: 20

\begin{tabular}{llll}
\hline R-squared & 0.996304 & Mean dependent var & 25.04202 \\
Adjusted R-squared & 0.995611 & S.D. dependent var & 0.187023 \\
S.E. of regression & 0.012391 & Sum squared resid & 0.002456 \\
Durbin-Watson stat & 0.592138 & & \\
\hline \hline
\end{tabular}




\section{GMM-HAC Estimate of the model with instruments but without autocorrelation correction}

System: SYS13

Estimation Method: Generalized Method of Moments

Date: 04/14/05 Time: 12:26

Sample: 19832002

Included observations: 20

Total system (unbalanced) observations 58

Estimation settings: tol $=0.00010$, derivs $=$ analytic

Initial Values: $\mathrm{C}(1)=0.07746, \mathrm{C}(2)=0.05659, \mathrm{C}(4)=0.38046, \mathrm{C}(5)=$

$-2.06240, C(11)=317057 ., C(12)=0.01516$

Kernel: Bartlett, Bandwidth: Fixed (2), No prewhitening

Iterate coefficients after one-step weighting matrix

Convergence achieved after: 1 weight matrix, 3 total coef iterations

\begin{tabular}{crrrr}
\hline \hline & Coefficient & Std. Error & t-Statistic & Prob. \\
\hline \hline $\mathrm{C}(1)$ & 0.079559 & 0.016565 & 4.802917 & 0.0000 \\
$\mathrm{C}(2)$ & 0.055240 & 0.011016 & 5.014384 & 0.0000 \\
$\mathrm{C}(4)$ & 0.379642 & 0.034433 & 11.02561 & 0.0000 \\
$\mathrm{C}(5)$ & -2.055264 & 0.159857 & -12.85692 & 0.0000 \\
$\mathrm{C}(11)$ & 318821.7 & 5275.564 & 60.43368 & 0.0000 \\
$\mathrm{C}(12)$ & 0.014975 & 0.000179 & 83.49802 & 0.0000 \\
\hline \hline \\
Determinant residual covariance & $8.25 \mathrm{E}-12$ & & \\
J-statistic & & 0.384913 & & \\
\hline \hline
\end{tabular}

Equation: DDEBTGDP $+S^{*}(1-$ RAVR*DEBTGDP(-1)-CFCK*KR2(-1)

$/ G D P R)=C(1)+C(2)^{*} K R 2(-1) / G D P R-C(2)^{*}$ DEBTGDP $(-1)$

Instruments: C KR2(-1)/GDPR DEBTGDP(-1) KR2(-2)/GDPR(-1)

DEBTGDP(-2) KR2(-3)/GDPR(-2) DEBTGDP(-3) KR2(-4)/GDPR(

-3) DEBTGDP(-4)

Observations: 19

\begin{tabular}{llll}
\hline R-squared & 0.057294 & Mean dependent var & 0.168757 \\
Adjusted R-squared & 0.001840 & S.D. dependent var & 0.014246 \\
S.E. of regression & 0.014233 & Sum squared resid & 0.003444 \\
Durbin-Watson stat & 0.597822 & &
\end{tabular}

Equation: LOG(KR2(-1)/GDPR $(+0))=($ LNRPLUSD $-\operatorname{LOG}(\mathrm{C}(4))) /(-1$

$+\mathrm{C}(5))$

Instruments: C LNRPLUSD

Observations: 19

\begin{tabular}{llll}
\hline R-squared & 0.728871 & Mean dependent var & 0.541292 \\
Adjusted R-squared & 0.712923 & S.D. dependent var & 0.057766 \\
S.E. of regression & 0.030951 & Sum squared resid & 0.016285 \\
Durbin-Watson stat & 0.596007 & & \\
\hline \hline
\end{tabular}


Equation: $\operatorname{LOG}(\mathrm{GDPR})=(1 / \mathrm{C}(5))^{\star} \mathrm{LOG}\left(\mathrm{C}(4)^{*}\left(\mathrm{KR} 2(-1)^{\wedge} \mathrm{C}(5)\right)+(1-\mathrm{C}(4))\right.$

$\left.{ }^{*}\left(\mathrm{C}(11)^{*}\left(\mathrm{EXP}\left(\mathrm{C}(12)^{\star} \mathrm{T}\right)\right)^{\star} \mathrm{EMPL}\right)^{\wedge} \mathrm{C}(5)\right)$

Instruments: C KR2(-1) T EMPL KR2(-2) KR2(-3) KR2(-4)

Observations: 20

\begin{tabular}{llll}
\hline R-squared & 0.996241 & Mean dependent var & 25.04202 \\
Adjusted R-squared & 0.995536 & S.D. dependent var & 0.187023 \\
S.E. of regression & 0.012496 & Sum squared resid & 0.002498 \\
Durbin-Watson stat & 0.581363 & & \\
\hline \hline
\end{tabular}

\section{GMM-HAC Estimate of the model with instruments and autocorrelation correction}

System: SYS14

Estimation Method: Generalized Method of Moments

Date: 04/15/05 Time: 14:36

Sample: 19832002

Included obsvations: 20

Total system (unbalanced) observations 58

Estimation settings: tol.00010, derivs $=$ analytic

Initial Values: $\mathrm{C}(1)=0.00281, \mathrm{C}(2)=0.04483, \mathrm{C}(3)=0.09800$,

$C(6)=0.86852, C(7)=-0.27857, C(4)=0.10977, C(5)=-5.47842$,

$C(8)=0.81616, C(9)=-0.30459, C(10)=0.38719,)=351595$.,

$C(12)=0.01649$

Kernel: Bartlett, Bandwidth: Fixed (2), No prewhitening

Iterate coefficients after one-step weighting matrix

Convergence achieved after: 1 weight matrix, 4 total coef iterations

\begin{tabular}{crrrr}
\hline \hline & Coefficient & Std. Error & t-Statistic & Prob. \\
\hline \hline C(1) & -0.001514 & 0.017017 & -0.088981 & 0.9295 \\
$\mathrm{C}(2)$ & 0.048399 & 0.008984 & 5.387269 & 0.0000 \\
$\mathrm{C}(3)$ & 0.100570 & 0.014171 & 7.097155 & 0.0000 \\
$\mathrm{C}(6)$ & 0.855877 & 0.083868 & 10.20509 & 0.0000 \\
$\mathrm{C}(7)$ & -0.273396 & 0.071719 & -3.812059 & 0.0004 \\
$\mathrm{C}(4)$ & 0.110437 & 0.009251 & 11.93839 & 0.0000 \\
$\mathrm{C}(5)$ & -5.415859 & 0.274054 & -19.76203 & 0.0000 \\
$\mathrm{C}(8)$ & 0.789403 & 0.036404 & 21.68425 & 0.0000 \\
$\mathrm{C}(9)$ & -0.272284 & 0.054988 & -4.951730 & 0.0000 \\
$\mathrm{C}(10)$ & 0.378495 & 0.026645 & 14.20487 & 0.0000 \\
$\mathrm{C}(11)$ & 351159.8 & 2291.267 & 153.2601 & 0.0000 \\
$\mathrm{C}(12)$ & 0.016529 & 0.000225 & 73.30994 & 0.0000 \\
\hline \hline
\end{tabular}

Equation: DDEBTGDP + $S^{*}(1-$ RAVR*DEBTGDP(-1)-CFCK*KR2(-1) 
/GDPR $)=\mathrm{C}(1)+\mathrm{C}(2)^{*} \mathrm{KR} 2(-1) / \mathrm{GDPR}-\mathrm{C}(3)^{*} \mathrm{DEBTGDP}(-1)+\mathrm{C}(6)^{*}($

DDEBTGDP $(-1)+S(-1)^{*}\left(1-\operatorname{RAVR}(-1)^{*} \operatorname{DEBTGDP}(-2)-\mathrm{CFCK}(-1)\right.$

*KR2(-2)/GDPR(-1)) ) + C(7)*( DDEBTGDP(-2) +S(-2)*(1 - RAVR(

$\left.-2)^{*} \operatorname{DEBTGDP}(-3)-\operatorname{CFCK}(-2)^{\star} \mathrm{KR} 2(-3) / G D P R(-2)\right)$ )

Instruments: C KR2(-1)/GDPR DEBTGDP(-1) (DDEBTGDP(-1) +S(-1)

*(1 - RAVR(-1)*DEBTGDP(-2)-CFCK(-1)*KR2(-2)/GDPR(-1)) )

(DDEBTGDP $(-2)+S(-2)^{*}\left(1-\operatorname{RAVR}(-2)^{*}\right.$ DEBTGDP(-3)-CFCK $(-2)$

*KR2(-3)/GDPR(-2)) ) KR2(-2)/GDPR(-1) DEBTGDP(-2)

(DDEBTGDP $(-3)+S(-3)^{*}\left(1-\mathrm{RAVR}(-3)^{*}\right.$ DEBTGDP(-4)-CFCK(-3)

$\left.\left.{ }^{*} K R 2(-4) / G D P R(-3)\right)\right)\left(\operatorname{DDEBTGDP}(-4)+S(-4)^{*}(1\right.$ - RAVR(-4)

${ }^{*}$ DEBTGDP(-5)-CFCK(-4)*KR2(-5)/GDPR(-4)) )

Observations: 19

\begin{tabular}{llll}
\hline R-squared & 0.697539 & Mean dependent var & 0.168757 \\
Adjusted R-squared & 0.611121 & S.D. dependent var & 0.014246 \\
S.E. of regression & 0.008884 & Sum squared resid & 0.001105 \\
Durbin-Watson stat & 1.837222 & & \\
\hline \hline
\end{tabular}

Equation: LOG(KR2(-1)/GDPR(+0)) $=(\operatorname{LNRPLUSD}-\operatorname{LOG}(\mathrm{C}(4))) /(-1$

$+C(5))+C(8)^{*} \operatorname{LOG}(\mathrm{KR} 2(-2) / G D P R(-1))+C(9)^{*} \operatorname{LOG}(\mathrm{KR} 2(-3) / G D P R($

$-2))+C(10)^{*} \operatorname{LOG}(\mathrm{KR} 2(-4) / G D P R(-3))$

Instruments: C LNRPLUSD LOG(KR2(-2)/GDPR(-1)) LOG(KR2(-3)

/GDPR(-2)) LOG(KR2(-4)/GDPR(-3)) LOG(KR2(-5)/GDPR(-4))

LOG(KR2(-6)/GDPR(-5))

Observations: 19

\begin{tabular}{llll}
\hline R-squared & 0.972500 & Mean dependent var & 0.541292 \\
Adjusted R-squared & 0.964643 & S.D. dependent var & 0.057766 \\
S.E. of regression & 0.010862 & Sum squared resid & 0.001652 \\
Durbin-Watson stat & 1.272446 & & \\
\hline
\end{tabular}

Equation: $\operatorname{LOG}(\mathrm{GDPR})=(1 / \mathrm{C}(5))^{*} \operatorname{LOG}\left(\mathrm{C}(4)^{*}\left(\mathrm{KR} 2(-1)^{\wedge} \mathrm{C}(5)\right)+(1-\mathrm{C}(4))\right.$

$\left.{ }^{*}\left(\mathrm{C}(11)^{*}\left(\operatorname{EXP}\left(\mathrm{C}(12)^{*} \mathrm{~T}\right)\right)^{*} \mathrm{EMPL}\right){ }^{\wedge} \mathrm{C}(5)\right)$

Instruments: C KR2(-1) T EMPL KR2(-2) KR2(-3) KR2(-4) KR2(-5)

Observations: 20

\begin{tabular}{llll}
\hline R-squared & 0.995577 & Mean dependent var & 25.04202 \\
Adjusted R-squared & 0.994748 & S.D. dependent var & 0.187023 \\
S.E. of regression & 0.013554 & Sum squared resid & 0.002939 \\
Durbin-Watson stat & 0.410307 & & \\
\hline \hline
\end{tabular}


Appendix F (NOT FOR PUBLICATION):

Residuals of Regressions 2 in Table 6
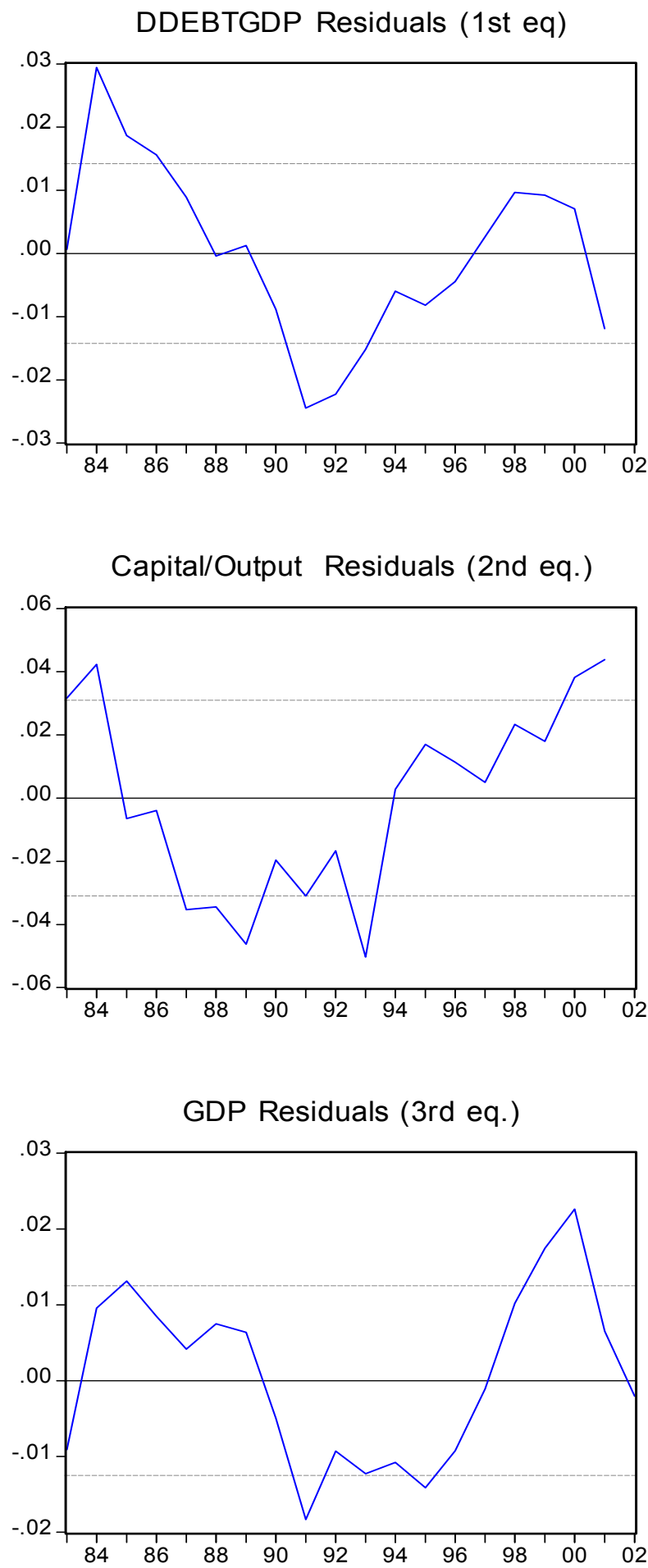
Residuals of Regressions 3 in Table 6
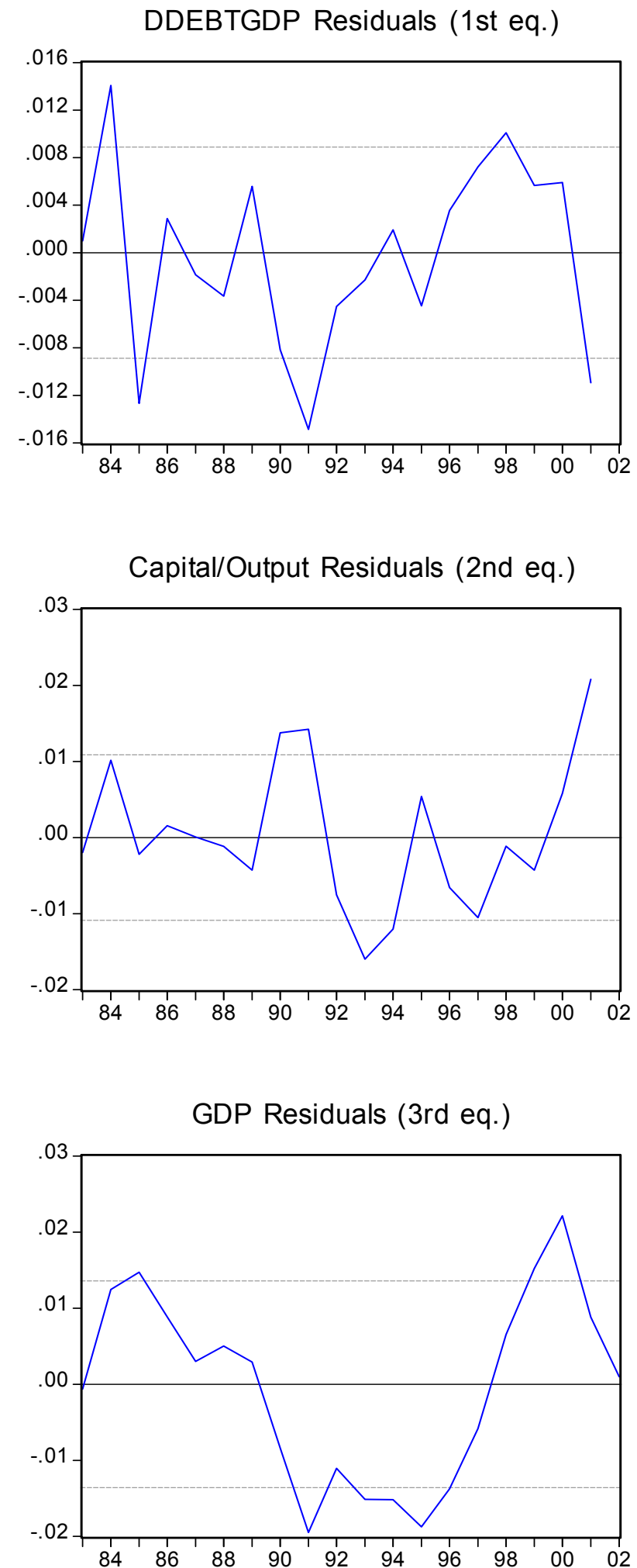